\title{
EFFECT OF DEFICIT IRRIGATION, NITROGEN AND POTASSIUM FERTILIZATION ON SUGAR BEET PRODUCTIVITY IN SANDY SOILS
}

\author{
B.S.I. Makhlouf ${ }^{(1)}$ and A.E.A. Abd El-All ${ }^{(2)}$ \\ (1) Sugar Crops Res. Inst., Agric. Res. Center, Giza, Egypt \\ (2) Soils \&Water and Environment Res. Inst., Agric. Res. Center, Giza, Egypt
}

Received: Apr. 20, 2017

Accepted: Apr. 29, 2017

\begin{abstract}
Two field experiments were carried out in a sandy soil in El-Bostan area, Aly Mubark Experimental Farm, Southern El-Tahrir region, (latitude of $30.57^{\circ} \mathrm{N}$ and longitude of $30.71^{\circ}$ E), El-Buhira Governorate, Egypt, during the two successive seasons of 2013/2014 and 2014/2015 to find out sufficient amount of irrigation water and the optimal levels of nitrogen and potassium fertilizers to get the highest yield and quality of sugar beet grown in a sandy soil under drip irrigation system conditions. A split plot design with three replications was used to lay out eighteen treatments, represented the combinations of three deficit irrigation regimes (applying irrigation water at $60 \%, 80 \%$ and $100 \%$ of the actual crop evapotranspiration "ET $T_{c}$ "), which occupied the main plots, whereas six combinations among three nitrogen fertilization

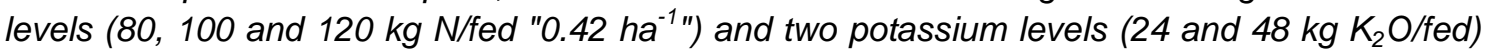
were distributed randomly in the sub-plots. Sugar beet Sara multi-germ variety was sown in both seasons.
\end{abstract}

Results revealed that irrigating sugar beet at $80 \% E T_{c}$ significantly increased root length and diameter, sucrose\%, extractable sugar\% (ES) and purity\% in both seasons. However, applying water at $100 \% E T_{c}$ significantly increased leaf area index (LAI), $K$ and $\alpha$-amino $N$ contents in root as well as top, root and sugar yields/fed in both seasons. Increasing potassium fertilizer level to $48 \mathrm{~kg} \mathrm{~K} \mathrm{~K}_{2} \mathrm{O} / \mathrm{fed}$ significantly increased all traits under study, except purity\% significantly decreased, in both seasons, meanwhile the increment in ES\% did not reach to the significant level in the $1^{\text {st }}$ season. Root length and diameter, $\mathrm{Na}, \mathrm{K}$ and $\alpha$-amino $\mathrm{N}$ contents, $L A l$, top, root and sugar yields/fed were significantly increased by increasing nitrogen levels from 80 to $120 \mathrm{~kg}$ $\mathrm{N} / \mathrm{fed}$, whereas adding $100 \mathrm{~kg} \mathrm{~N} / \mathrm{fed}$ gave the highest significant values of sucrose\% and ES\%, in both seasons. The combination between water regime at $80 \% E T_{c}$ and $48 \mathrm{~kg} \mathrm{~K}_{2} \mathrm{O} / \mathrm{fed}$ gave the highest averages of root length, sucrose\% and ES\%, in both seasons. The combination between water regime at $100 \% E T_{c}$ and $48 \mathrm{~kg} \mathrm{~K}_{2} \mathrm{O} / \mathrm{fed}$ significantly increased root yields/fed in both seasons, as well as sugar yield/fed in the $1^{\text {st }}$ one. The addition of water at $100 \% E T_{c}$ with $120 \mathrm{~kg} \mathrm{~N} / f e d$ significantly increased root diameter, LAl and yields of top, root and sugar/fed in both seasons. Sucrose\%, ES\% and purity\% significantly increased by the application of water at $80 \% E T_{c}$ and $100 \mathrm{~kg} \mathrm{~N} / \mathrm{fed}$ in both seasons. The combination between $48 \mathrm{~kg} \mathrm{~K}_{2} \mathrm{O} / \mathrm{fed}$ and 100 $\mathrm{kg} \mathrm{N} /$ fed produced the highest significant values of sucrose\% and ES\%, in the $1^{\text {st }}$ season.

Water use efficiency (WUE) calculated on root and/or suger yield basis increased with decreasing the amount of applied irrigation water indicating that deficit irrigation regime is a good tool to increase WUE for sugar beet under drip irrigation condition in sandy soil.

Based on the previous results, the application of irrigation water at $80 \% E T_{c}$ with the addition of $48 \mathrm{~kg} \mathrm{~K} \mathrm{~K}_{2} \mathrm{O} / \mathrm{fed}$ and $100 \mathrm{~kg} \mathrm{~N} / \mathrm{fed}$ could be recommended to get the best quality, while the combination of $100 \% E T_{c}$, $48 \mathrm{~kg} \mathrm{~K} \mathrm{~K}_{2} \mathrm{O} / \mathrm{fed}$ and $120 \mathrm{~kg} \mathrm{~N} / \mathrm{fed}$ is recommended to get the highest yields of sugar beet grown in a sandy soil under drip irrigation at El-Bostan, El-Buhira Governorate.

Keywords: Sugar beet, dip irrigation system, water stress, water use efficiency, nitrogen and potassium 


\section{INTRODUCTION}

It is well known that Egypt suffers from a scarcity of water, in a time the Egyptians try to expand the arable area to reach selfsatisfaction in some strategic crops and commodities while their population is rapidly increased. Therefore, increasing water use efficiency became a vital demand. Water use rationalization is a good tool to achieve this goal through the usage of drip irrigation, especially in the newly reclaimed soils. The potential benefits of deficit irrigation are increasing irrigation water use efficiency (WUE), reducing irrigation costs and water opportunity costs (English and Raja, 1996). In this respect, Weeden (2000) indicated that irrigation water was applied at levels of between 500 and $1000 \mathrm{~mm}$ for production of sugar beet in areas like the USA, Egypt and Pakistan. In addition, Hussein et al. (2015) revealed that the highest growth parameters were obtained by irrigation with $75 \%$ of $\mathrm{ET}_{\mathrm{c}}$, while the lowest values were gained under the highest water stress ( $50 \%$ of the $\mathrm{ET}_{\mathrm{c}}$ ). There was high positive correlation between transpiration and root yield of sugar beet (Stewart and Hagan 1973, Dunham 1995 and Ucan and Gencoúglan 2004). Tognetti et al. (2002) evaluated some water regimes (50, 75, 100 and $120 \%$ of $\mathrm{ET}_{\circ}$ and unirrigated). They found that the root yield and sucrose\% increased with increasing water quantity, while the unirrigated gave the lowest a-amino $\mathrm{N}$. Hosseinpour et al. (2006) found that increasing water quantity increased root yield and leaf area, and decreased WUE for root and sugar yields. They added that the highest root yield was recorded with $100 \%$ of $\mathrm{ET}_{0}$, while $25 \% \mathrm{ET}_{0}$ treatment resulted in the highest WUE for root and sugar yields. Mahmoodi et al. (2008) affirmed that the highest root and sugar yields and quality traits were obtained under $70 \%$ of field capacity (FC) compared to $90 \%$ FC. Esmaeili (2011) reported that continuous water stress achieved the highest WUE. Masri et al. (2015) revealed that $75 \% \mathrm{ET}_{\mathrm{c}}$ water regime under drip gave the highest values of LAI, sucrose and purity percentages. Meantime, increasing IWR led to increasing impurities\%.

Under conditions of sandy soils, mostly characterized with poor nutrients and light texture, good management of applying nutrients and irrigation water are considered of paramount importance to obtain an economic yield of cultivated crops.

Nitrogen and potassium are the most promoting nutrients for sugar beet to achieve high root yield and quality traits. Supplying sugar beet with NK was responsible for root size, considered as the sugar storage (Barlog et al. 2013). Potassium is an important element for sugar beet yield and quality, in balance with other essential plant nutrients ( $\mathrm{Li}$ and Liang, 1997). Kant and Kafkafi (2002) and Wang et al. (2013) mentioned that K plays significant roles in increasing root elongation, depth, enlarging root absorptive surface, maintaining turgor by reducing water loss and wilting and maximizing water retention in plant tissue, nutrients uptake, phloem unloading. They added that $\mathrm{K}$ enhances the photosynthetic products translocation from the source (leaves) to the sink organs (roots), which subsequently increases the plant dry matter and leads to an increase in the storage root growth. Mehrandish et al. (2012) reported that the highest root and sugar yields were observed with $100 \mathrm{~kg} \mathrm{~K} \mathrm{~K}_{2} \mathrm{O} / \mathrm{ha}$, which also improved quantitative and qualitative characteristics under deficit irrigation. Amin et al. (2013) indicated that applying $100 \mathrm{~kg} \mathrm{~N} / \mathrm{fed}$ gave the highest root length and diameter, impurities and yields of top, root and sugar. Meanwhile, sucrose\% decreased with increasing $\mathrm{N}$ rates from 50 to $100 \mathrm{~kg} \mathrm{~N} / \mathrm{fed}$. El-Sarag and Moselhy (2013) showed that the highest gross sugar, top, root yields were obtained by adding $211 \mathrm{~kg} \mathrm{~N} / \mathrm{ha}$ and $140 \mathrm{~kg} \mathrm{~K} \mathrm{~K}_{2} \mathrm{O} / \mathrm{ha}$. The maximum sucrose\% was achieved by adding $141 \mathrm{~kg} \mathrm{~N} / \mathrm{ha}$ and $100 \mathrm{~kg} \mathrm{~K}{ }_{2} \mathrm{O} / \mathrm{ha}$. Mehran and Saadat (2013) 
cleared that adding $114 \mathrm{~kg} \mathrm{~K} \mathrm{~K}_{2} \mathrm{O} / \mathrm{ha}$ under different rates of $\mathrm{N}$ significantly increased sucrose $\%$, root and sugar yields/fed. Increasing $\mathrm{N}$ level up to $285 \mathrm{~kg} \mathrm{~N} /$ ha without $\mathrm{K}$ fertilization led to a significant increase in impurities\%. Neseim et al. (2014) found that the drought stress significantly reduced root morphological, root and white sugar yields. Meanwhile, insignificant differences were found in $\mathrm{Na}, \mathrm{K}, \alpha$-amino $\mathrm{N}$, sucrose $\%$ and purity $\%$. In addition, adding $75 \mathrm{~K}_{2} \mathrm{O} \mathrm{kg} / \mathrm{fed}$ gave the highest yield, sucrose $\%$ and the lowest impurities\% under drought stress. Also, adding $100 \mathrm{~kg} \mathrm{~K} \mathrm{~K}_{2} \mathrm{O} / \mathrm{fed}$ gave the highest root and sugar yields and WUE under sufficient irrigation. El-Geddawy and Makhlouf (2015) pointed out that roots length, diameter and fresh weight, $\mathrm{K}$ and $\mathrm{Na}$ contents, top, root and sugar yields were significantly increased by increasing nitrogen up to $120 \mathrm{~kg} \mathrm{~N} / \mathrm{fed}$. The highest sucrose \% was recorded with $100 \mathrm{~kg} \mathrm{~N} / \mathrm{fed}$. Masri et al. (2015) mentioned that increasing $\mathrm{N}$ rate up to $120 \mathrm{~kg} \mathrm{~N} / \mathrm{fed}$ significantly increased root weight/plant, impurities\%, root and white sugar yields. They added that the excessive $\mathrm{N}$ application lowered sucrose, purity and extractable sugar percentages. Badr (2016) indicated that applying $110 \mathrm{~kg} \mathrm{~N} / \mathrm{fed}$ gave the highest fresh root and top yields. Moreover, adding $70 \mathrm{~kg}$ $\mathrm{N} / \mathrm{fed}$ produced the maximum sucrose, extractable sugar and purity percentages. Sugar yield was significantly increased by increasing $\mathrm{N}$ level up to $90 \mathrm{~kg} \mathrm{~N} / \mathrm{fed}$.

This work was conducted to find out the optimal water regime, nitrogen and potassium levels to attain the maximum root and sugar yields with the best quality traits of sugar beet crop grown in a sandy soil under drip irrigation system as well as to raise water use efficiency.

\section{MATERIALS AND METHODS}

Two field experiments were carried out in a sandy soil in El-Bostan area, Aly Mubark Experimental Farm, Southern El-Tahrir region, (latitude of $30.57^{\circ} \mathrm{N}$ and longitude of $\left.30.71^{\circ} \mathrm{E}\right)$, El-Buhira Governorate, Egypt, during the two successive seasons of $2013 / 2014$ and $2014 / 2015$ to find out the optimal levels of nitrogen and potassium fertilizers and appropriate irrigation regime to get the highest yield and quality of sugar beet grown in a sandy soil under drip irrigation system conditions. A split plot design with three replications was used to lay out eighteen treatments, represented the combinations of three deficit irrigation regimes (applying of irrigation water at $60 \%$, $80 \%$ and $100 \%$ of the actual crop evapotranspiration "ETc"), which occupied the main plots, whereas six combinations between three nitrogen levels $(80,100$ and $120 \mathrm{~kg} \mathrm{~N} / \mathrm{fed}$ ) and two potassium levels (24 and $48 \quad \mathrm{~kg} \quad \mathrm{~K}_{2} \mathrm{O} / \mathrm{fed}$ ) were distributed randomly in the sub plots. The sub plot area was $24 \mathrm{~m}^{2}$ including 4 ridges of $60 \mathrm{~cm}$ in width and $10 \mathrm{~m}$ in length with $25 \mathrm{~cm}$ between hills. Drip irrigation system used in the present work consisted of a main delivery pipeline (PE, $32 \mathrm{~mm}$ ) and a submain line (PE, $25 \mathrm{~mm}$ ). The drip laterals were of polyethylene material $(16 \mathrm{~mm}$ diameter), with inline emitters spaced at 25$\mathrm{cm}$ apart. The discharge rate of the emitter was 4 liters $/ \mathrm{h}$. Overall dose of $30 \mathrm{~kg}$ $\mathrm{P}_{2} \mathrm{O}_{5} / \mathrm{fed}$ was added in form of super phosphate $\left(\begin{array}{lll}15 \% & \mathrm{P}_{2} \mathrm{O}_{5}\end{array}\right)$ during seed bed preparation. Nitrogen fertilizer was added in form of ammonium nitrate $(33.5 \% \mathrm{~N})$ in 5 equal dose; the $1^{\text {st }}$ one was added after thinning (4-true leaf stage) and the other four doses were applied at 2-week interval after the first application. Potassium was added in 3-equal dose in form of potassium sulfate $\left(48 \% \mathrm{~K}_{2} \mathrm{O}\right)$, the $1^{\text {st }}$ one was applied with the $3^{\text {rd }}$ dose of nitrogen and the other two ones were added at the same time of applying nitrogen doses. Sugar beet variety namely Sara was sown in the $1^{\text {st }}$ week of October, while harvesting was done at age of 210 days in both seasons. The preceding crop was maize followed by fallow. Other field practices were done as recommended by Sugar Crop Research Institute, Agriculture Research Center. After sowing sugar beet seeds, a total amount of $45 \mathrm{~mm}$ 
water $\left(189 \mathrm{~m}^{3}\right)$ was daily applied at four irrigations to ensure full emergence of sugar beet plants, thereafter, the studied irrigation regimes were applied. Soil samples were collected before planting to determine some soil physical and chemical characteristics of the experimental site (Table 1). Soil analyses were done according to the methods shown by Piper (1950), Chapman and Pratt (1961), Jackson (1967), Markus et al. (1982) and Soltanpour (1991).

\section{Measurements and calculations:}

A. Calculations related to irrigation:

\section{Reference Evapotranspiration $\left(E T_{0}\right)$ :}

The values of the reference evapotranspiration $\left(E_{0}\right)$ were calculated using average of the previous five years of weather data obtained from South El-Tahrir Metrological Station using Penman-Monteith equation, CROPWAT model (Allen et al. 1998). The crop evapotranspiration $\left(E T_{c}\right)$ values were calculated according to the following equation:

$$
\mathrm{ET}_{\mathrm{c}}=\mathrm{ET}_{\mathrm{o}} * \mathrm{~K}_{\mathrm{c}}
$$

Where; $\mathrm{ET}_{\mathrm{c}}$ : crop evapotranspiration ( $\mathrm{mm} /$ day), $\mathrm{ET}_{\mathrm{o}}$ : reference evapotranspiration ( $\mathrm{mm} /$ day) and $\mathrm{K}_{\mathrm{c}}$ : crop coefficient values for sugar beet crop (Table 2).

Table 1: Soil physical and chemical characteristics of the experimental site for 2013/2014 and 2014/2015 seasons

\begin{tabular}{|c|c|c|c|c|c|c|c|c|c|c|}
\hline \multicolumn{11}{|c|}{ 2013/2014 season } \\
\hline \multirow{2}{*}{$\begin{array}{l}\text { Soil depth } \\
\quad(\mathrm{cm})\end{array}$} & \multicolumn{3}{|c|}{$\begin{array}{l}\text { Particle size } \\
\text { distribution \% }\end{array}$} & \multirow{2}{*}{$\begin{array}{l}\text { Texture } \\
\text { class }\end{array}$} & \multicolumn{3}{|c|}{$\begin{array}{l}\text { Available nutrients } \\
\text { (mg/kg soil) }\end{array}$} & \multirow{2}{*}{$\begin{array}{l}\mathrm{FC} \\
\%\end{array}$} & \multirow[t]{2}{*}{ WP \% } & \multirow{2}{*}{$\begin{array}{c}\text { AW } \\
\%\end{array}$} \\
\hline & Sand & Silt & Clay & & $\mathrm{N}$ & $P$ & $\mathrm{~K}$ & & & \\
\hline $0-15$ & 92.6 & 2.9 & 4.5 & Sandy & 12.55 & 8.14 & 80.1 & 12.3 & 5.3 & 7.0 \\
\hline $15-30$ & 91.3 & 4.7 & 4.0 & Sandy & 10.11 & 7.15 & 60.17 & 12.0 & 5.2 & 6.8 \\
\hline $30-45$ & 90.5 & 5.5 & 4.0 & Sandy & 6.45 & 5.75 & 40.70 & 11.1 & 4.3 & 6.8 \\
\hline \multirow{2}{*}{$\begin{array}{l}\text { Soil depth } \\
\quad(\mathrm{cm})\end{array}$} & \multirow{2}{*}{$\underset{\mathrm{g} / \mathrm{cm}^{3}}{\mathrm{~b}_{\mathrm{b}}}$} & \multirow{2}{*}{$\begin{array}{c}E C \\
\mathrm{ds} / \mathrm{cm}\end{array}$} & \multirow{2}{*}{$\mathrm{pH}$} & \multicolumn{7}{|c|}{ Soluble cations and anions (meq/l) } \\
\hline & & & & $\mathrm{Ca}^{+2}$ & $\mathrm{Mg}^{+2}$ & $\mathrm{Na}^{+}$ & $\mathrm{K}^{+}$ & $\mathrm{HCO}_{3}^{-}$ & $\mathrm{SO}_{4}^{-2}$ & $\mathrm{Cl}^{-}$ \\
\hline $0-15$ & 1.43 & 0.37 & 8.6 & 1.20 & 0.65 & 1.6 & 0.20 & 1.17 & 0.58 & 1.9 \\
\hline $15-30$ & 1.60 & 0.39 & 8.8 & 1.31 & 0.61 & 1.7 & 0.25 & 1.21 & 0.55 & 2.1 \\
\hline $30-45$ & 1.71 & 0.41 & 8.8 & 1.40 & 0.62 & 1.8 & 0.30 & 1.25 & 0.64 & 2.2 \\
\hline \multicolumn{11}{|c|}{ 2014/2015 season } \\
\hline \multirow{2}{*}{$\begin{array}{l}\text { Soil depth } \\
\quad(\mathrm{cm})\end{array}$} & \multicolumn{3}{|c|}{$\begin{array}{l}\text { Particle size } \\
\text { distribution \% }\end{array}$} & \multirow{2}{*}{$\begin{array}{l}\text { Texture } \\
\text { class }\end{array}$} & \multicolumn{3}{|c|}{$\begin{array}{c}\text { Available nutrients } \\
\text { (mg/kg soil) }\end{array}$} & \multirow{2}{*}{$\begin{array}{l}\text { FC } \\
\%\end{array}$} & \multirow{2}{*}{$\begin{array}{l}\text { WP } \\
\%\end{array}$} & \multirow{2}{*}{$\begin{array}{c}\text { AW } \\
\%\end{array}$} \\
\hline & Sand & Silt & Clay & & $\mathrm{N}$ & $\mathrm{P}$ & $\mathrm{K}$ & & & \\
\hline $0-15$ & 90.6 & 5.3 & 4.1 & Sandy & 14.75 & 8.56 & 80.98 & 12.5 & 5.40 & 7.10 \\
\hline $15-30$ & 91.2 & 4.8 & 4.0 & Sandy & 12.10 & 6.87 & 73.51 & 11.87 & 4.99 & 6.88 \\
\hline $30-45$ & 92.7 & 3.0 & 4.3 & Sandy & 7.35 & 5.75 & 57.16 & 11.12 & 4.48 & 6.64 \\
\hline \multirow{2}{*}{$\begin{array}{l}\text { Soil depth } \\
\text { (cm) }\end{array}$} & \multirow{2}{*}{$\mathrm{D}_{\mathrm{b}} \mathrm{g} / \mathrm{cm}^{-}$} & \multirow{2}{*}{$\begin{array}{c}E C \\
\mathrm{ds} / \mathrm{cm}\end{array}$} & \multirow{2}{*}{$\mathrm{pH}$} & \multicolumn{7}{|c|}{ Soluble cations and anions (meq/l) } \\
\hline & & & & $\mathrm{Ca}^{+2}$ & $\mathrm{Mg}^{+2}$ & $\mathrm{Na}^{+}$ & $\mathrm{K}^{+}$ & $\mathrm{HCO}_{3}^{-}$ & $\mathrm{SO}_{4}^{-2}$ & $\mathrm{Cl}^{-}$ \\
\hline $0-15$ & 1.42 & 0.37 & 8.5 & 1.16 & 0.75 & 1.52 & 0.30 & 1.15 & 0.65 & 1.93 \\
\hline $15-30$ & 1.57 & 0.40 & 8.4 & 1.33 & 0.65 & 1.67 & 0.35 & 1.13 & 0.56 & 2.30 \\
\hline $30-45$ & 1.70 & 0.42 & 8.4 & 1.42 & 0.62 & 1.77 & 0.39 & 1.29 & 0.74 & 2.16 \\
\hline
\end{tabular}




\section{Applied Irrigation Water:}

The amounts of the applied irrigation water (AIW) were calculated according to the equation given by Vermeiren and Jopling (1984) as follows:

$$
\text { AIW }=\frac{E T_{C} * K_{r} * 1}{E_{a}}+L R
$$

Where: AIW: depth of applied irrigation water $(\mathrm{mm}), \mathrm{ET}_{\mathrm{c}}$ : crop evapotranspiration $(\mathrm{mm} /$ day $), \quad \mathrm{K}_{\mathrm{r}}$ : evaporation reduction coefficient, that depends on ground cover. A value of 1.0 was used "where the spacing between drip lines is less than $1.8 \mathrm{~m}$, FAO,56" (Allen et al., 1998), I: irrigation intervals (day), $E_{a}$ : irrigation efficiency of the drip irrigation system, "an average value of $90 \%$ was used" and LR: leaching requirements, $10 \%$ of the calculated applied irrigation water was additionally applied perirrigation during the growing season for leaching purposes". The total amount of applied irrigation water under the studied water regimes $60 \%, 80 \%$ and $100 \% \mathrm{ET}_{\mathrm{c}}$ were 1642.9, 2190.5 and $2738.2 \mathrm{~m}^{3} / \mathrm{fed}$, respectively.

Irrigation time was determined before each irrigation event by measuring the actual emitter discharge according to the equation given by Ismail (2002) as follows:

$$
t=\frac{A I W * A}{q}
$$

Where: $\mathrm{t}$ : irrigation time (h), AIW: applied irrigation water $(\mathrm{mm}), \mathrm{A}$ : wetted area $\left(\mathrm{m}^{2}\right)$ and q: emitter discharge (liter/h).
Crop coefficient values (as shown by Allen et al., 1998) are presented in Table 2.

\section{Water Use Efficiency (WUE):}

Water Use efficiency $\left(\mathrm{kg} / \mathrm{m}^{3}\right)$ was calculated according to Jensen (1983) as follows:

WUE $_{\text {root yield }}=$ root yield $(\mathrm{kg} / \mathrm{fed}) /$ applied irrigation water $\left(\mathrm{m}^{3} / \mathrm{fed}\right)$

WUE $_{\text {sugar yield }}=$ sugar yield $(\mathrm{kg} / \mathrm{fed}) /$ applied irrigation water $\left(\mathrm{m}^{3} / \mathrm{fed}\right)$

\section{B. Criteria of sugar beet crop:}

A representative sample of ten plants was randomly taken from the guarded rows of each sub-plot after 120 days from sowing to determine the following characteristics:

1. Leaf area index (LAl), which was determined in 10 leaf disks of $1.0 \mathrm{~cm}$ diameter using the "disk method" described by Watson (1958) and then the following equation was used:

LAI = leaf area per plant $\left(\mathrm{cm}^{2}\right) /$ plant ground area $\left(\mathrm{cm}^{2}\right)$

2. Photosynthetic pigments were determined in the fresh leaves according to the method described by Wettestien (1957).

Chl. "a" mg/g.f.w. = 9.684 (A 662) -0.99

$$
\text { (A 644). }
$$

Chl. "b" mg/g.f.w. $=21.426$ (A 644) -4.65

$$
\text { (A 662). }
$$

Carot. $\quad$ mg/g.f.w. $=4.695$ (A 440) -0.268

$$
\text { ( chl. "a" + chl. "b"). }
$$

Where: chl. "a", "b" and carot.: concentrations of chlorophylls "a", "b" and carotenoids, respectively, and $A$ : optical density at the wave length indicated.

Table 2: Sugar beet crop coefficients.

\begin{tabular}{lccc}
\hline \multicolumn{1}{c}{ Growth stage } & & Crop coefficient $\left(\mathrm{K}_{\mathrm{c}}\right)$ \\
\cline { 1 - 2 } \multicolumn{1}{c}{ Stage } & Period (day) & 0.35 \\
Initial stage & 35 & 1.2 \\
Development & 60 & 0.7 \\
Mid stage & 70 & 0.5 \\
Late stage & 40 & \\
\hline
\end{tabular}


At harvest, a sample of ten plants was randomly taken from the middle rows of each sub-plot to determine the following traits:

1. Root length $(\mathrm{cm})$.

2. Root diameter $(\mathrm{cm})$.

3. Potassium and sodium concentrations (meq/100 g beet) in roots were determined using "flame photometer" according to Brown and Lilliland (1964). Alpha amino nitrogen concentration determined using Hydrogenation method according to Pergel (1945).

4. Sucrose percentage was determined as described by Le Docte (1927).

5. Extractable sugar\% (ES) was calculated according to Dexter et al. (1967) as follows: ES \% = sucrose \% - sugar lost to molasses - 0.6

6. Purity $\%$ was calculated according to Deviller (1988) as follows:

Purity \% $=99.36-[14.27(\mathrm{Na}+\mathrm{K}+$ a-amino N) / sucrose\%].

7. Top and root yields, which were determined on sub-plot weight $(\mathrm{kg})$ and converted to tons/fed.

8. Sugar yield was calculated according to the following equation:

Sugar yield $($ ton $/ \mathrm{fed})=$ extractable sugar\% $x$ root yield (ton/fed).

\section{Statistical analysis:}

The collected data were statistically analyzed as shown by Snedecor and Cochran (1981). Least significant difference (LSD) was used to compare the differences between treatment means at $5 \%$ level of probability as mentioned by Waller and Duncan (1969).

\section{RESULTS AND DISCUSSION}

\section{A. Agronomical and physiological characteristics: \\ 1. Root length:}

Data in Table 3 showed that root length was significantly affected by the studied irrigation water regimes (IWR) in both seasons. The results cleared a statistical positive response to increasing the amount of irrigation water up to $80 \% \mathrm{ET}_{c}$, while decreasing amount of irrigation water to $60 \% \mathrm{ET}_{\mathrm{c}}$ and/or increasing it to $100 \%$ led to reductions in root length, in both seasons. Decreasing IWR from $100 \%$ to $80 \% \mathrm{ET}_{\mathrm{c}}$ led to significant increases in root length amounted to $24.24 \%$ and $13.03 \%$, in the $1^{\text {st }}$ and $2^{\text {nd }}$ season, respectively. The reduction in the root elongation could be referred to the reduction in soil moisture, which could influence NK uptakes and its rate of diffusion which in turn reduced the root elongation (Grzebisz et al. 2013).

Raising potassium level from 24 to $48 \mathrm{~kg}$ $\mathrm{K}_{2} \mathrm{O} / \mathrm{fed}$ led to a gradual and significant increase in root length in both seasons. The effective role of potassium comes through its influence in storing materials of metabolic process, which may be used partially in plant growth in terms of root length and thickness. The effectiveness of potassium on root elongation was reported by Mehran and Samad (2013).

There was a significant positive response of this trait with increasing the applied level of nitrogen fertilizer. The positive influence of nitrogen could be due to its role in cell division and elongation as a principal component in chlorophyll component. This result is in agreement with that reported by Amin et al. (2013) and El-Geddawy and Makhlouf (2015).

The interaction between water regimes and nitrogen levels showed a significant influence on root length in both seasons. Applying irrigation water at $80 \% \mathrm{ET}_{\mathrm{c}}$ attained the highest values of this trait compared to the other two water regimes, when plants were fertilized with $120 \mathrm{~kg} \mathrm{~N} / \mathrm{fed}$ in both seasons. Regarding to the significant $\mathrm{N} \times \mathrm{K}$ interaction, the highest significant value of root length were achieved by the application of $48 \mathrm{~kg} \mathrm{~K} \mathrm{~K}_{2} \mathrm{O} / \mathrm{fed}$ combined with $120 \mathrm{~kg}$ $\mathrm{N} /$ fed in the $1^{\text {st }}$ season. 


\section{Root diameter:}

Data in Table 3 clear that the applied water regimes achieved a significant influence on root diameter in the $1^{\text {st }}$ and $2^{\text {nd }}$ seasons. It was found that applying water at $100 \% \mathrm{ET}_{\mathrm{c}}$ over passed the other two IWR in this trait.

The results pointed to a significant positive increase in root diameter due to the increase in $\mathrm{K}$ fertilization level to $48 \mathrm{~kg}$ $\mathrm{K}_{2} \mathrm{O} / \mathrm{fed}$ in both seasons. The effectiveness of potassium on root growth was reported by Neseim et al. (2014).

Table 3 affirmed that root diameter significantly responded to the gradual increase in the applied N-level up to $120 \mathrm{~kg}$ $\mathrm{N} / \mathrm{fed}$ in both seasons. This result may be referred to the important role of nitrogen in enhancing plant growth and building-up its organs. This result coincides with those found by Amin et al. (2013).

The interaction between water regimes and nitrogen fertilization levels attained a significant effect on root diameter in both seasons. Meanwhile, the interaction between water regimes and potassium fertilization levels had a significant influence on this trait in the $1^{\text {st }}$ season only.

\section{Leaf area index (LAI):}

Data in Table 3 cleared that the evaluated water regimes had a significant effect on LAI in both seasons. The highest LAI values were obtained from beets given $100 \% \mathrm{ET}_{\mathrm{c}}$, while the lowest ones were recorded by beets irrigated at $60 \% \mathrm{ET}_{\mathrm{c}}$, in the $1^{\text {st }}$ and $2^{\text {nd }}$ season. These results are in accordance with those obtained by Hosseinpour et al. (2006). Also, Waston (1952) reported that the size and longevity of sugar beet leaf canopies strongly influenced by soil moisture.

Increasing potassium fertilizer level from 24 to $48 \mathrm{~kg} \mathrm{~K} \mathrm{~K}_{2} \mathrm{O} / \mathrm{fed}$ caused a significant increase in the values of LAI, in the two growing seasons (Table 3). This result may be attributed to the role of potassium in increasing cell volume and hence increasing leaf area/plant.
The results indicated that increasing nitrogen level from 80 up to $120 \mathrm{~kg} \mathrm{~N} / \mathrm{fed}$ led to a significant increase in LAl. This finding may be due to the role of nitrogen in cell elongation and increasing the vegetative growth. These results are in agreement with those confirmed by Kandil et al. (2002).

Leaf area index was significantly influenced by the interaction between water regimes and nitrogen fertilizer levels in both seasons (Table 3). Applying water at $100 \%$ $\mathrm{ET}_{\mathrm{c}}$ with $120 \mathrm{~kg} \mathrm{~N} / \mathrm{fed}$ gave the highest values of LAl compared to the other two water regimes in both seasons. The interaction between water regime and potassium fertilization significantly affected on LAI in the $1^{\text {st }}$ season only.

\section{Photosynthetic pigments:}

Leaf pigments substances refer to the contents of chlorophyll "a", "b" and carotenoids. Nitrogen is an essential element in the synthesis of chlorophyll, and in turn photosynthesis and the released energy. Also, potassium and iron elements have vital functions in the formation of chlorophyll.

Data in Table 4 cleared that the amount of irrigation water given at $80 \% \mathrm{ET}_{\mathrm{c}}$ attained significant increments in chlorophyll "a" and "b" over the other two irrigation regimes, in both seasons. The values of carotenoids significantly decreased as the amount of the applied irrigation water decreased in the $2^{\text {nd }}$ season only. These results were in agreement with Chutia and Borah (2012) and Xiang et al. (2013), who mentioned that drought stress, caused a significant decrease and degradation in chlorophyll "a", "b" as well as total chlorophyll content.

Regarding potassium and nitrogen effects on photosynthetic pigments, results cleared a statistical positive response to the applied levels of potassium and/or nitrogen. Adding $48 \mathrm{~kg} \mathrm{~K} \mathrm{~K}_{2} \mathrm{O} / \mathrm{fed}$ and/or nitrogen up to $120 \mathrm{~kg} \mathrm{~N} / \mathrm{fed}$ significantly raised the values of photosynthetic pigments in both seasons. 
Table 3: Root length (cm), root diameter $(\mathrm{cm})$ and leaf area index (LAl) as affected by water regimes, nitrogen and potassium fertilizers and their interactions in 2013/2014 and 2014/2015 seasons

\begin{tabular}{|c|c|c|c|c|c|c|c|c|c|}
\hline \multirow{2}{*}{\multicolumn{2}{|c|}{ Treatments }} & \multicolumn{8}{|c|}{ Root length (cm) } \\
\hline & & & 201 & 2014 & & & 201 & 2015 & \\
\hline \multirow{2}{*}{$\begin{array}{l}\text { Water } \\
\text { regimes }\end{array}$} & \multirow{2}{*}{$\begin{array}{l}\text { Potassium } \\
\text { levels (kg } \\
\left.\mathrm{K}_{2} \mathrm{O} / \mathrm{fed}\right)\end{array}$} & \multicolumn{8}{|c|}{ Nitrogen levels (kg N/fed) } \\
\hline & & 80 & 100 & 120 & Mean & 80 & 100 & 120 & Mean \\
\hline \multirow{2}{*}{$60 \% \mathrm{ET}_{\mathrm{c}}$} & 24 & 19.78 & 22.00 & 24.33 & 22.04 & 18.22 & 20.89 & 22.67 & 20.59 \\
\hline & 48 & 22.45 & 24.33 & 26.56 & 24.45 & 20.11 & 22.55 & 25.00 & 22.56 \\
\hline \multicolumn{2}{|c|}{ Mean } & 21.11 & 23.17 & 25.45 & 23.24 & 19.17 & 21.72 & 23.84 & 21.57 \\
\hline \multirow{2}{*}{$80 \% \mathrm{ET}_{\mathrm{c}}$} & 24 & 22.89 & 24.11 & 27.55 & 24.85 & 18.89 & 21.55 & 25.67 & 22.04 \\
\hline & 48 & 24.11 & 26.44 & 30.45 & 27.00 & 20.44 & 23.89 & 27.44 & 23.93 \\
\hline \multicolumn{2}{|c|}{ Mean } & 23.50 & 25.28 & 29.00 & 25.93 & 19.67 & 22.72 & 26.56 & 22.98 \\
\hline \multirow{3}{*}{$100 \% \mathrm{ET}_{\mathrm{c}}$} & 24 & 17.78 & 19.89 & 22.11 & 19.93 & 16.78 & 20.56 & 21.55 & 19.63 \\
\hline & 48 & 19.11 & 21.33 & 25.00 & 21.81 & 18.22 & 21.67 & 23.22 & 21.04 \\
\hline & Mean & 18.44 & 20.61 & 23.56 & 20.87 & 17.50 & 21.11 & 22.39 & 20.33 \\
\hline Potassium $\mathrm{x}$ & 24 & 20.15 & 22.00 & 24.67 & 22.27 & 17.96 & 21.00 & 23.30 & 20.75 \\
\hline \multirow{2}{*}{ Nitrogen } & 48 & 21.89 & 24.04 & 27.33 & 24.42 & 19.59 & 22.70 & 25.22 & 22.51 \\
\hline & & 21.02 & 23.02 & 26.00 & & 18.78 & 21.85 & 24.26 & \\
\hline \multicolumn{10}{|c|}{ LSD at 0.05 level for: } \\
\hline \multirow{4}{*}{\multicolumn{2}{|c|}{$\begin{array}{l}\text { Water regimes }(A) \\
\text { Potassium levels }(B) \\
\text { Nitrogen levels }(C) \\
A \times B\end{array}$}} & \multicolumn{2}{|c|}{1.70} & $A \times C$ & 0.64 & $A$ & 1.51 & $A \times C$ & 0.70 \\
\hline & & \multicolumn{2}{|c|}{0.30} & $B \times C$ & 0.52 & B & 0.33 & $B \times C$ & NS \\
\hline & & & & $\mathrm{A} \times \mathrm{B} \times \mathrm{C}$ & NS & C & 0.40 & $\mathrm{~A} \times \mathrm{B} \times \mathrm{C}$ & NS \\
\hline & & & & & & $A \times B$ & NS & & \\
\hline & & & & & Root dia & $\operatorname{ter}(\mathrm{cm})$ & & & \\
\hline & 24 & 8.56 & 9.22 & 10.67 & 9.48 & 7.44 & 8.89 & 9.33 & 8.56 \\
\hline $\mathrm{bU} \%$ E $\mathrm{I}_{\mathrm{c}}$ & 48 & 9.22 & 9.45 & 11.00 & 9.89 & 8.28 & 9.11 & 9.89 & 9.09 \\
\hline & & 8.89 & 9.34 & 10.84 & 9.69 & 7.86 & 9.00 & 9.61 & 8.82 \\
\hline & 24 & 11.00 & 11.89 & 12.56 & 11.82 & 10.33 & 11.00 & 11.22 & 10.85 \\
\hline $80 \%$ E $I_{c}$ & 48 & 11.89 & 12.44 & 12.89 & 12.41 & 10.89 & 11.44 & 11.89 & 11.41 \\
\hline & & 11.44 & 12.17 & 12.72 & 12.11 & 10.61 & 11.22 & 11.56 & 11.13 \\
\hline & 24 & 11.11 & 12.08 & 13.45 & 12.21 & 11.22 & 12.11 & 12.78 & 12.04 \\
\hline $100 \%$ ᄃ $\mathrm{C}$ & 48 & 12.33 & 12.67 & 14.56 & 13.19 & 11.89 & 12.67 & 13.89 & 12.82 \\
\hline & & 11.72 & 12.37 & 14.00 & 12.70 & 11.56 & 12.39 & 13.33 & 12.43 \\
\hline Potassium $x$ & 24 & 10.22 & 11.06 & 12.22 & 11.17 & 9.67 & 10.67 & 11.11 & 10.48 \\
\hline Nitrogen & 48 & 11.15 & 11.52 & 12.82 & 11.83 & 10.35 & 11.07 & 11.89 & 11.11 \\
\hline & & 10.68 & 11.29 & 12.52 & & 10.01 & 10.87 & 11.50 & \\
\hline LSD at 0.05 & for: & & & & & & & & \\
\hline Water regim & & & & $A \times C$ & 0.39 & A & 1.57 & $A \times C$ & 0.43 \\
\hline Potassium le & $(B)$ & & & $B \times C$ & NS & B & 0.20 & $B \times C$ & NS \\
\hline Nitrogen leve & & & & $\mathrm{A} \times \mathrm{B} \times \mathrm{C}$ & NS & $\mathrm{C}$ & 0.25 & $\mathrm{~A} \times \mathrm{B} \times \mathrm{C}$ & NS \\
\hline$A \times B$ & & & & & & $A \times B$ & NS & & \\
\hline & & & & & & & & & \\
\hline & 24 & 1.73 & 2.06 & 2.31 & 2.03 & 2.06 & 2.16 & 2.41 & 2.21 \\
\hline $\mathrm{bU} \%$ E $\mathrm{I}_{\mathrm{c}}$ & 48 & 1.92 & 2.36 & 2.60 & 2.29 & 2.21 & 2.23 & 2.54 & 2.33 \\
\hline & & 1.83 & 2.21 & 2.45 & 2.16 & 2.14 & 2.19 & 2.47 & 2.27 \\
\hline & 24 & 2.67 & 2.77 & 3.09 & 2.84 & 2.23 & 3.11 & 3.46 & 2.93 \\
\hline $80 \% \in I_{c}$ & 48 & 2.76 & 2.80 & 3.25 & 2.94 & 2.39 & 3.33 & 3.53 & 3.08 \\
\hline & & 2.71 & 2.78 & 3.17 & 2.89 & 2.31 & 3.22 & 3.49 & 3.01 \\
\hline & 24 & 3.41 & 3.52 & 3.68 & 3.53 & 3.35 & 3.54 & 3.57 & 3.49 \\
\hline $100 \%$ Elc & 48 & 3.48 & 3.54 & 3.73 & 3.58 & 3.50 & 3.62 & 3.72 & 3.61 \\
\hline & & 3.44 & 3.53 & 3.70 & 3.56 & 3.43 & 3.58 & 3.65 & 3.55 \\
\hline Potassium $x$ & 24 & 2.60 & 2.78 & 3.02 & 2.80 & 2.55 & 2.93 & 3.15 & 2.88 \\
\hline Nitrogen & 48 & 2.72 & 2.90 & 3.19 & 2.94 & 2.70 & 3.06 & 3.26 & 3.01 \\
\hline & & 2.66 & 2.84 & 3.11 & & 2.62 & 3.00 & 3.20 & \\
\hline LSD at 0.05 & el for: & & & & & & & & \\
\hline Water regim & & & & $A \times C$ & 0.12 & $A$ & 0.11 & $A \times C$ & 0.18 \\
\hline Potassium le & $(B)$ & & & $B \times C$ & NS & B & 0.08 & $B \times C$ & NS \\
\hline Nitrogen leve & & & & $\mathrm{A} \times \mathrm{B} \times \mathrm{C}$ & NS & C & 0.10 & $\mathrm{~A} \times \mathrm{B} \times \mathrm{C}$ & NS \\
\hline$A \times B$ & & & & & & $A \times B$ & NS & & \\
\hline
\end{tabular}

NS: Insignificant difference. 
Effect of deficit irrigation, nitrogen and potassium fertilization on sugar......

Table 4: Photosynthetic pigments (mg/g.f.w) as affected by water regimes, nitrogen and potassium fertilizers and their interactions in 2013/2014 and 2014/2015 seasons

\begin{tabular}{|c|c|c|c|c|c|c|c|c|c|}
\hline \multirow{2}{*}{\multicolumn{2}{|c|}{ Treatments }} & \multicolumn{8}{|c|}{ Chlorophyll a (mg/g.f.w) } \\
\hline & & & & 2014 & & & & 2015 & \\
\hline \multirow{2}{*}{$\begin{array}{l}\text { Water } \\
\text { regimes }\end{array}$} & \multirow{2}{*}{$\begin{array}{l}\text { Potassium levels } \\
\left(\mathrm{kg} \mathrm{K} \mathrm{K}_{2} \mathrm{O} / \mathrm{fed}\right)\end{array}$} & \multicolumn{8}{|c|}{ Nitrogen levels (kg N/fed) } \\
\hline & & 80 & 100 & 120 & Mean & 80 & 100 & 120 & Mean \\
\hline \multirow{2}{*}{$60 \% \mathrm{ET}_{\mathrm{c}}$} & 24 & 3.17 & 3.51 & 3.73 & 3.47 & 2.92 & 3.38 & 4.12 & 3.47 \\
\hline & 48 & 3.26 & 3.59 & 3.78 & 3.54 & 3.22 & 3.77 & 4.30 & 3.76 \\
\hline \multicolumn{2}{|r|}{ Mean } & 3.22 & 3.55 & 3.76 & 3.51 & 3.07 & 3.58 & 4.21 & 3.62 \\
\hline \multirow{3}{*}{$80 \% \mathrm{ET}_{\mathrm{c}}$} & 24 & 4.85 & 5.13 & 5.63 & 5.20 & 4.69 & 5.60 & 5.54 & 5.28 \\
\hline & \multirow[b]{2}{*}{ Mean } & 5.01 & 5.24 & 5.91 & 5.39 & 4.90 & 5.85 & 5.95 & 5.57 \\
\hline & & 4.93 & 5.19 & 5.77 & 5.29 & 4.79 & 5.73 & 5.75 & 5.42 \\
\hline \multirow{3}{*}{$100 \% \mathrm{ET}_{\mathrm{c}}$} & 24 & 4.26 & 5.02 & 5.20 & 4.83 & 4.73 & 4.89 & 5.23 & 4.95 \\
\hline & 48 & 4.67 & 5.14 & 5.32 & 5.04 & 4.85 & 4.96 & 5.39 & 5.07 \\
\hline & Mean & 4.46 & 5.08 & 5.26 & 4.93 & 4.79 & 4.93 & 5.31 & 5.01 \\
\hline Potassiumx & 24 & 4.09 & 4.55 & 4.85 & 4.50 & 4.11 & 4.62 & 4.96 & 4.57 \\
\hline Nitrogen & 48 & 4.31 & 4.66 & 5.00 & 4.66 & 4.32 & 4.86 & 5.21 & 4.80 \\
\hline \multicolumn{2}{|c|}{ Mean } & 4.20 & 4.60 & 4.93 & & 4.22 & 4.74 & 5.09 & \\
\hline \multirow{4}{*}{\multicolumn{2}{|c|}{$\begin{array}{l}\text { LSD at } 0.05 \text { level for: } \\
\text { Irrigation regimes }(A) \\
\text { Potassium levels }(B) \\
\text { Nitrogen levels }(C) \\
A \times B\end{array}$}} & & $A \times C$ & 0.23 & A & 0.42 & $A \times C$ & 0.39 \\
\hline & & \multicolumn{2}{|c|}{0.11} & $B \times C$ & NS & B & $\begin{array}{l}0.4 L \\
0.19\end{array}$ & $B \times C$ & NS \\
\hline & & & & $\mathrm{A} \times \mathrm{B} \times \mathrm{C}$ & NS & $\mathrm{C}$ & 0.23 & $\mathrm{~A} \times \mathrm{B} \times \mathrm{C}$ & NS \\
\hline & & & & & & $A \times B$ & NS & & \\
\hline & & & & & orophy & (mg/g.f & & & \\
\hline & 24 & 1.73 & 2.07 & 2.35 & 2.05 & 1.70 & 2.03 & 2.16 & 1.96 \\
\hline $60 \% E T_{c}$ & 48 & 2.06 & 2.21 & 2.50 & 2.25 & 2.05 & 2.26 & 2.44 & 2.25 \\
\hline & Mean & 1.89 & 2.14 & 2.42 & 2.15 & 1.87 & 2.15 & 2.30 & 2.11 \\
\hline ०० ० БT & 24 & 3.13 & 3.13 & 3.47 & 3.24 & 3.04 & 3.35 & 3.37 & 3.25 \\
\hline $80 \% \mathrm{El}_{\mathrm{c}}$ & 48 & 3.22 & 3.25 & 3.40 & 3.29 & 3.11 & 3.37 & 3.52 & 3.34 \\
\hline & Mean & 3.18 & 3.19 & 3.44 & 3.27 & 3.08 & 3.36 & 3.45 & 3.29 \\
\hline & 24 & 2.46 & 2.61 & 2.88 & 2.65 & 2.76 & 2.84 & 2.96 & 2.86 \\
\hline $100 \% E I_{c}$ & 48 & 2.75 & 2.85 & 3.06 & 2.89 & 2.93 & 3.11 & 3.24 & 3.09 \\
\hline & Mean & 2.61 & 2.73 & 2.97 & 2.77 & 2.85 & 2.97 & 3.10 & 2.97 \\
\hline Potassiumx & 24 & 2.44 & 2.60 & 2.90 & 2.65 & 2.50 & 2.74 & 2.83 & 2.69 \\
\hline Nitrogen & 48 & 2.68 & 2.77 & 2.99 & 2.81 & 2.70 & 2.91 & 3.07 & 2.89 \\
\hline & Mean & 2.56 & 2.69 & 2.94 & 2.73 & 2.60 & 2.83 & 2.95 & \\
\hline LSD at 0.05 & level for: & & & & & & & & \\
\hline Water regim & hes $(A)$ & & & $A \times C$ & NS & A & 0.07 & $A \times C$ & 0.09 \\
\hline Potassium le & evels (B) & & & $B \times C$ & NS & B & 0.04 & $B \times C$ & NS \\
\hline Nitrogen leve & els (C) & & & $\mathrm{AxB} \times \mathrm{C}$ & NS & $\mathrm{C}$ & 0.05 & $\mathrm{AxB} \times \mathrm{C}$ & NS \\
\hline$A \times B$ & & & & & & $A \times B$ & 0.07 & & \\
\hline & & & & & otenoic & mg/g.f. & & & \\
\hline & 24 & 1.15 & 1.21 & 1.58 & 1.31 & 0.92 & 1.17 & 1.28 & 1.12 \\
\hline $60 \% E T_{c}$ & 48 & 1.20 & 1.27 & 1.70 & 1.39 & 1.09 & 1.22 & 1.17 & 1.16 \\
\hline & Mean & 1.18 & 1.24 & 1.64 & 1.35 & 1.01 & 1.20 & 1.23 & 1.14 \\
\hline & 24 & 1.11 & 1.21 & 1.67 & 1.33 & 1.38 & 1.47 & 1.71 & 1.52 \\
\hline $80 \% \mathrm{El}_{\mathrm{c}}$ & 48 & 1.46 & 1.54 & 1.78 & 1.59 & 1.55 & 1.67 & 1.80 & 1.67 \\
\hline & Mean & 1.28 & 1.38 & 1.73 & 1.46 & 1.46 & 1.57 & 1.76 & 1.60 \\
\hline & 24 & 1.07 & 1.20 & 1.51 & 1.26 & 1.36 & 1.60 & 1.84 & 1.60 \\
\hline $100 \% E I_{c}$ & 48 & 1.21 & 1.34 & 1.73 & 1.43 & 1.54 & 1.73 & 2.01 & 1.76 \\
\hline & Mean & 1.14 & 1.27 & 1.62 & 1.34 & 1.45 & 1.66 & 1.93 & 1.68 \\
\hline Potassiumx & 24 & 1.11 & 1.21 & 1.59 & 1.30 & 1.22 & 1.41 & 1.61 & 1.41 \\
\hline Nitrogen & 48 & 1.29 & 1.39 & 1.74 & 1.47 & 1.39 & 1.54 & 1.66 & 1.53 \\
\hline & Mean & 1.20 & 1.30 & 1.66 & & 1.31 & 1.48 & 1.64 & \\
\hline LSD at 0.05 & level for: & & & & & & & & \\
\hline Water regim & es $(A)$ & & & $A \times C$ & NS & A & 0.39 & $A \times C$ & NS \\
\hline Potassium le & evels (B) & & & $B \times C$ & NS & B & 0.06 & $B \times C$ & NS \\
\hline Nitrogen leve & els $(C)$ & & & $\mathrm{AxB} \times \mathrm{C}$ & NS & C & 0.08 & $\mathrm{AxB} \times \mathrm{C}$ & NS \\
\hline$A \times B$ & & & & & & $A \times B$ & NS & & \\
\hline
\end{tabular}

NS: Insignificant difference. 
The interaction between water regimes and nitrogen levels caused significant effects on chlorophyll "a" in both seasons, and chlorophyll "b" in the $2^{\text {nd }}$ one. In addition, chlorophyll "b" was significantly affected by the interaction between water regimes and potassium fertilization levels in both seasons as well as carotenoids in the $1^{\text {st }}$ season.

\section{B. Juice quality and chemical constituents: \\ 1. Potassium, sodium and $\alpha$-amino $N$ concentrations in roots:}

Increasing the impurities in sugar beet roots negatively affect the amount of the extracted sugar. Data in Table 5 pointed out that supplying beets with water at $80 \% \mathrm{ET}_{\mathrm{c}}$ led to significant decrease in $\alpha$-amino $\mathrm{N}$ and $\mathrm{K}$ contents in roots in both seasons as well as $\mathrm{Na}$ in the $1^{\text {st }}$ season.

The results cleared that the difference between potassium fertilization levels in their influence on the values of $\alpha$-amino $\mathrm{N}, \mathrm{K}$ and $\mathrm{Na}$ was significant in both seasons. Raising $\mathrm{K}$-fertilizer level to $48 \mathrm{~K}_{2} \mathrm{O} / \mathrm{fed}$ resulted in the highest a-amino $\mathrm{N}, \mathrm{K}$ and $\mathrm{Na}$ contents in roots. The effective role of potassium on impurities content has been reported by Neseim et al. (2014).

Data revealed that raising $\mathrm{N}$-fertilizer doses from 80 up to $120 \mathrm{~kg} \mathrm{~N} / \mathrm{fed}$ continuously and significantly increased the values of a-amino $\mathrm{N}, \mathrm{K}$ and $\mathrm{Na}$, in both seasons. These results may be due to nitrogen effects in increasing root length and diameter (Table 3), hence increased the absorption of $\mathrm{N}, \mathrm{K}$ and $\mathrm{Na}$. These results were in agreement with El-Geddawy and Makhlouf (2015).

The interaction between water regime and nitrogen fertilization led to significant effects on the values of $\alpha$-amino $N$ and $K$ contents in roots in both seasons as well as $\mathrm{Na}$ in the $2^{\text {nd }}$ season. The contents of sodium in root were significantly affected by the interaction between potassium and nitrogen fertilization in both seasons. In addition, a-amino $\mathrm{N}$ content in roots was significantly affected by the interaction between water regimes and potassium fertilizer levels in the $1^{\text {st }}$ season only.

\section{Sucrose and extractable sugar percentages:}

Data in Table 6 pointed out that the amount of irrigation water given to sugar beet at $80 \% \mathrm{ET}_{\mathrm{c}}$ achieved the highest values of sucrose and extractable sugar percentages in the $1^{\text {st }}$ and $2^{\text {nd }}$ seasons compared to the other two irrigation regimes. In this respect, Dreesman et al. (1994) and Bloch et al. (2006) mentioned that drought stress decreased the photosynthetic rate, transpiration rate and stomatal conductance of sugar beet, which resulted in a reduction in sucrose $\%$.

There was a significant and continuous response of sucrose\% to increasing the applied dose of potassium fertilizer. Increasing $\mathrm{K}$ level to $48 \mathrm{~kg} \mathrm{~K}_{2} \mathrm{O} / \mathrm{fed}$ significantly increased sucrose $\%$ in both seasons and extractable sugar\% in the $2^{\text {nd }}$ one. Such increases in these traits may be referred to the distinguished role of potassium in biosynthesis and transfer of sucrose to storage roots. In this concern, Grzebisz et al. (2013) mentioned that the transportation of assimilates in the phloem is also $\mathrm{K}$ concentration-dependent.

The results in Table 6 cleared that adding $100 \mathrm{~kg} \mathrm{~N} / \mathrm{fed}$ was enough to produce the highest and significant values of sucrose and extractable sugar in both seasons. However, it could be noticed that increasing nitrogen level up to $120 \mathrm{~kg} \mathrm{~N} / \mathrm{fed}$ reduced the values of sucrose and extractable sugar percentages. These results may be due to that the extreme application of $\mathrm{N}$ causes an imbalanced partitioning of assimilates among leaves and storage root, and leads to decreasing sucrose concentration. This result coincides with those found by ElGeddawy and Makhlouf (2015). 
Table 5: Alpha amino N, potassium and sodium concentrations as affected by water regimes, nitrogen and potassium fertilizers and their interactions in 2013/2014 and $2014 / 2015$ seasons

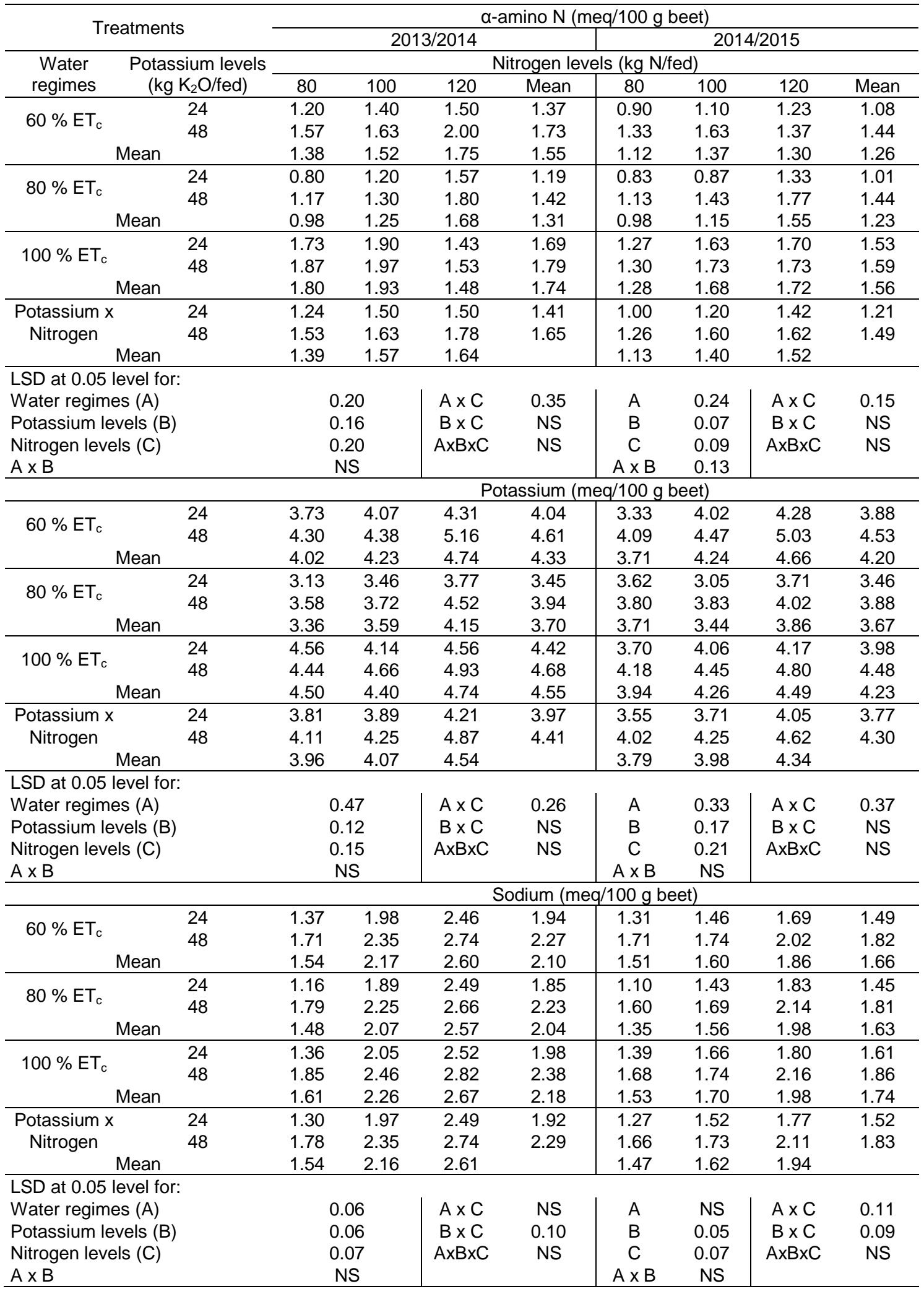


Table 6: Sucrose, extractable sugar and purity percentages as affected by water regimes, nitrogen and potassium fertilizers and their interactions in 2013/2014 and 2014/2015 seasons

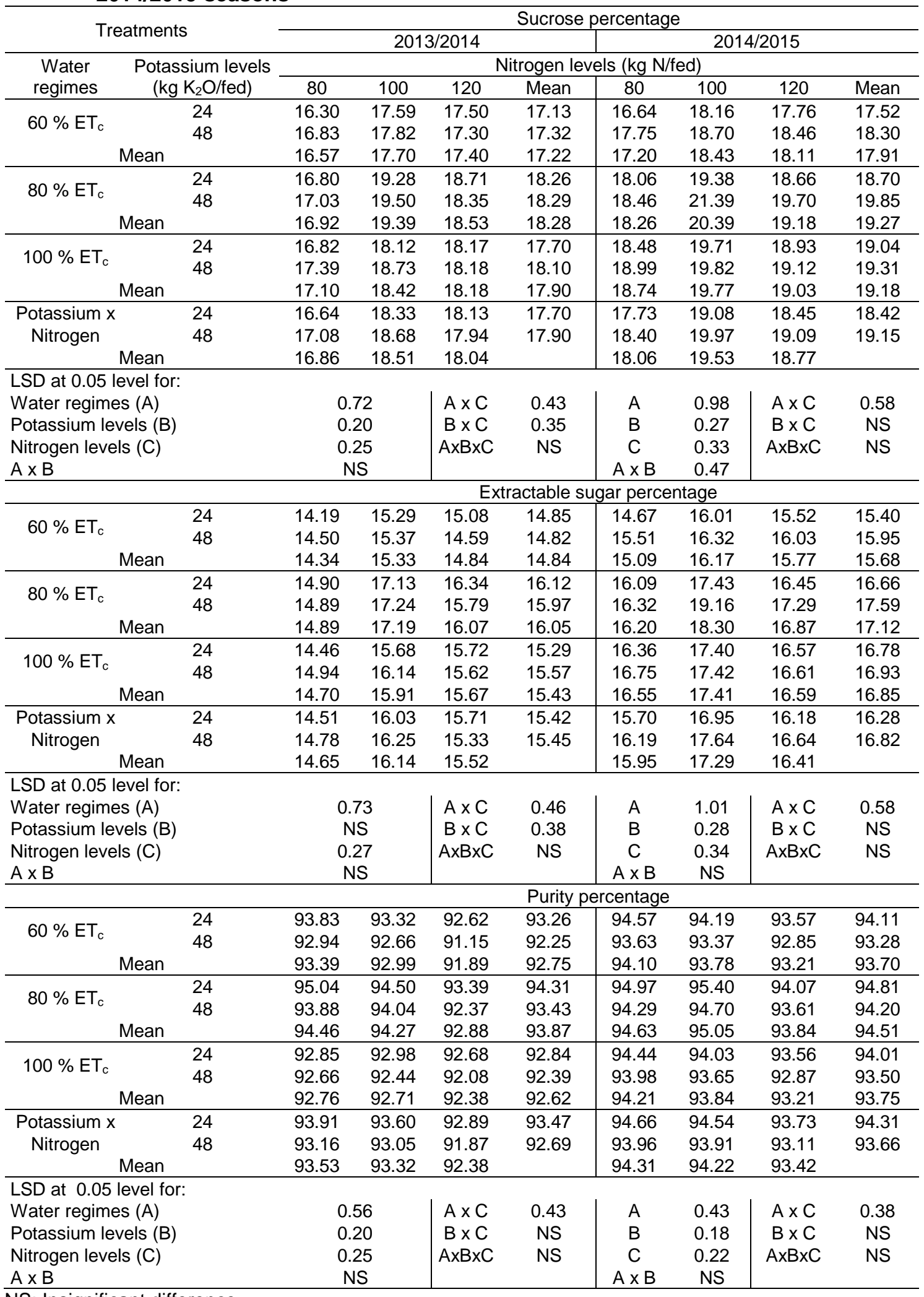

NS: Insignificant difference. 
The interaction between water regimes and nitrogen fertilizers had significant effects in sucrose and extractable sugar percentages in both seasons. Sucrose\% was significantly affected by the interaction between water regimes and potassium levels in the $2^{\text {nd }}$ season. In addition, the interaction between potassium and nitrogen fertilization levels significantly affected sucrose and extractable sugar percentages in the $1^{\text {st }}$ season.

\section{Purity percentage:}

Results in Table 6 cleared that purity\% similarly responded to the evaluated water regimes as sucrose \% did in the $1^{\text {st }}$ season only, where the middle IWR ( $80 \%$ ETc) gave the highest positive and significant value of purity $\%$. This influence might be due to the pronounced effect of this IWR on sucrose\% which is considered the main component in juice, where the higher the sucrose $\%$, the higher the purity\%. This result is in agreement with that reported by Mahmoodi et al. (2008) and Masri et al. (2015) in their studies.

The results pointed to a significant increase in the values of purity\% as the applied dose of potassium was raised from 24 to $48 \mathrm{~kg} \mathrm{~K} \mathrm{~K}_{2} \mathrm{O} / \mathrm{fed}$, in both seasons.

The highest values of purity\% were attained with the middle nitrogen fertilization level, i.e. $100 \mathrm{~kg} \mathrm{~N} / \mathrm{fed}$. Raising the added N dose to $120 \mathrm{~kg} \mathrm{~N} / \mathrm{fed}$ depressed the values of purity \% in both seasons. The reduction in purity \% accompanied the increase in $\mathrm{N}$ level beyond $100 \mathrm{~kg} \mathrm{~N} / \mathrm{fed}$ could be attributed to the increase in impurities\% (Table 5) and the reduction in sucrose \% (Table 6). This finding was in line with those stated by ElGeddawy and Makhlouf (2015).

All studied interactions showed insignificant effects on purity percentage, except the interaction between water regime and nitrogen fertilization, which was significant in both seasons, it could be noticed that the highest values of this mentioned trait were recorded by the combination between water regime at $80 \%$ $\mathrm{ET}_{\mathrm{c}}$ and $100 \mathrm{~kg} \mathrm{~N} / \mathrm{fed}$, in both seasons.

\section{Top, root and sugar yields/fed: 1. Top yield:}

Data in Table 7 show that increasing the amount of irrigation water to $80 \%$ and $100 \%$ $\mathrm{ET}_{\mathrm{c}}$ significantly increased top yield/fed by (2.85 and 3.52 tons) and (2.73 and 4.31 tons) in the $1^{\text {st }}$ and $2^{\text {nd }}$ season, respectively compared to that gained by applying water at $60 \% \mathrm{ET}_{\mathrm{c}}$.

The application of $\mathrm{K}$ fertilizer significantly increased the values of top fresh yield/fed in both seasons. The increment of top fresh yield/fed as a result of increasing $\mathrm{K}$ level to $48 \mathrm{~kg} \mathrm{~K}_{2} \mathrm{O} / \mathrm{fed}$ amounted to $4.37 \%$ (0.40 ton) in the $1^{\text {st }}$ season, corresponding to $4.85 \%$ (0.48 tons) in the $2^{\text {nd }}$ one, respectively. These results are in agreement with those of El-Sarag and Moselhy (2013).

Data in Table 7 illustrate a positive and significant response of top yield/fed to the gradual increase in the applied $\mathrm{N}$ fertilization level up to $120 \mathrm{~kg} \mathrm{~N} / \mathrm{fed}$. Raising $\mathrm{N}$ level to 100 and $120 \mathrm{~kg} \mathrm{~N} /$ fed improved top yield by $9.05 \%$ and $21.06 \%$ in the $1^{\text {st }}$ season, corresponding to $7.69 \%$ and $16.77 \%$ in the $2^{\text {nd }}$ one, respectively compared to $80 \mathrm{~kg}$ $\mathrm{N} / \mathrm{fed}$. These findings referred to the important role of nitrogen in enhancing plant growth and building up its organs. These findings are in line with those stated by Amin et al. (2013) and Badr (2016).

Top yield/fed was significantly affected by the interaction between IWR and $\mathrm{N}$ fertilizer in both seasons as well as the interaction between $\mathrm{K}$ and $\mathrm{N}$ fertilizers in the $2^{\text {nd }}$ one.

\section{Root yield:}

Results in Table 7 demonstrated that the root yield was significantly and positively responded to the gradual increase in the amount of irrigation water in both seasons. Increasing the applied irrigation water to $80 \%$ and $100 \% \mathrm{ET}_{\mathrm{c}}$ given to sugar beet led 
to an increase in root yield/fed of (3.33 and 6.23 tons) and ( 2.38 and 6.48 tons) in the $1^{\text {st }}$ and $2^{\text {nd }}$ season, respectively compared to that irrigating beets at $60 \% \mathrm{ET}_{\mathrm{c}}$. These results were in agreement with those reported by Hosseinpour et al. (2006) and Mahmoodi et al. (2008). In the same respect, Clover et al. (1999) affirmed that drought stress reduced root yield, due to root weight reduction/plant.

The results pointed out that root yield significantly increased with increasing $\mathrm{K}$ fertilizer level to $48 \mathrm{~kg} \mathrm{~K} \mathrm{~K}_{2} \mathrm{O} / \mathrm{fed}$, in both seasons. This finding may be attributed to the stimulatory effect of potassium fertilizer on the rate of photosynthesis. These results were in agreement with Neseim et al. (2014).

Supplying sugar beet with 100 and 120 $\mathrm{kg} \mathrm{N} /$ fed significantly improved root yield/fed by $9.35 \%$ (1.7 tons) and $23.92 \%$ (4.35 tons) in the $1^{\text {st }}$ season, corresponding to $14.59 \%$ (2.58 tons) and $30.03 \%$ (5.31 tons) in the $2^{\text {nd }}$ one, respectively compared to that fertilized with $80 \mathrm{~kg} \mathrm{~N} / \mathrm{fed}$. The relative influence of $\mathrm{N}$ fertilizer on root yield is mainly due to its positive effect on root growth in terms of root length and diameter (Table 3). These results are in agreement with those confirmed by El-Geddawy and Makhlouf (2015) and Badr (2016).

The interaction between water regimes and potassium levels had significant effects on root yield/fed, in both seasons. In the $1^{\text {st }}$ season, raising $K$ fertilization level from 24 to $48 \mathrm{~kg} \mathrm{~K} \mathrm{~K}_{2} \mathrm{O} / \mathrm{fed}$ with the application of water at $60 \% \mathrm{ET}_{\mathrm{c}}$ led to higher root yield/fed (2.36 tons) compared with that harvested at $80 \% \mathrm{ET}_{\mathrm{C}}(0.83$ ton) or that gained at $100 \%$ $\mathrm{ET}_{\mathrm{c}}$ (1.77 tons), indicating that applying irrigation at the lowest regimes $\left(60 \% \mathrm{ET}_{\mathrm{c}}\right)$ resulted in the highest WUE. In the $2^{\text {nd }}$ one, the difference between the two $\mathrm{K}$ levels in their effect on root yield was insignificant when sugar beet was irrigated at $80 \% \mathrm{ET}_{\mathrm{c}}$.
However, the difference between the two $\mathrm{K}$ levels reached the level of significance when IWR was applied at 60 and/or $100 \% \mathrm{ET}_{\mathrm{c}}$., it can be noticed that IWR of $60 \% \mathrm{ET}_{\mathrm{c}}$ recorded the highest WUE.

The interaction between water regimes and nitrogen levels had a significant effect on root yield/fed, in both seasons. These results coincided with those of El-Sarag and Moselhy (2013). In the $1^{\text {st }}$ season, it was found that raising $\mathrm{N}$ fertilization level from 80 to $100 \mathrm{~kg} \mathrm{~N} / \mathrm{fed}$ increased root yield/fed by $2.45,1.68$ and 0.96 tons, respectively, corresponding to increases of 5.77, 3.97 and 3.31 tons as $\mathrm{N}$ level was increased from 80 to $120 \mathrm{~kg} \mathrm{~N} / \mathrm{fed}$, when sugar beet was irrigated at 60,80 and $100 \% \mathrm{ET}_{\mathrm{c}}$, respectively. In the $2^{\text {nd }}$ season, the same trend was observed, showing that the gradual increase in the amount of water from 60 up to $100 \% E_{C}$ led to more leaching of the applied $\mathrm{N}$ doses beyond root zone, decreasing the opportunity of its absorption by plant roots in the sandy soil. Moreover, these results manifested that irrigation deficit at $60 \% \mathrm{ET}_{\mathrm{c}}$ recorded the highest water use efficiency.

\section{Sugar yield:}

Data in Table 7 revealed that applying irrigation water at $100 \% \mathrm{ET}_{\mathrm{c}}$ produced the highest sugar yield in both seasons due to its distinguished influence on root yield. Increasing the amount of irrigation water to $80 \%$ and $100 \% \mathrm{ET}_{\mathrm{c}}$ significantly increased sugar yield/fed by $30.15 \%$ ( 0.76 ton) and $42.46 \%(1.07$ ton $)$ in the $1^{\text {st }}$ season, corresponding to $24.17 \%$ (0.66 ton) and $47.25 \%(1.29$ ton $)$ in the $2^{\text {nd }}$ one, respectively compared to $60 \%$ ETc. Similar results were recorded by Masri et al. (2015). These findings coincide with those of Selim et al. (2010), who reported that the highest sugar yield was recorded with amount of $2653 \mathrm{~m}^{3}$ water/fed under drip irrigation in sandy soil. 
Effect of deficit irrigation, nitrogen and potassium fertilization on sugar......

Table 7: Top, root and sugar yields (tons/fed) as affected by water regimes, nitrogen and potassium fertilizers and their interactions in 2013/2014 and 2014/2015 seasons

\begin{tabular}{|c|c|c|c|c|c|c|c|c|c|}
\hline \multirow{2}{*}{\multicolumn{2}{|c|}{ Treatments }} & \multicolumn{8}{|c|}{ Top yield (ton/yield) } \\
\hline & & & 201 & 2014 & & & 201 & 2015 & \\
\hline \multirow{2}{*}{$\begin{array}{c}\text { Water } \\
\text { regimes }\end{array}$} & \multirow{2}{*}{$\begin{array}{l}\text { Potassium levels } \\
\left(\mathrm{kg} \mathrm{K}_{2} \mathrm{O} / \mathrm{fed}\right)\end{array}$} & \multicolumn{8}{|c|}{ Nitrogen levels ( $\mathrm{kg} \mathrm{N} / \mathrm{fed}$ ) } \\
\hline & & 80 & 100 & 120 & Mean & 80 & 100 & 120 & Mean \\
\hline \multirow[b]{2}{*}{$60 \% \mathrm{ET}_{\mathrm{c}}$} & 24 & 5.98 & 6.85 & 8.19 & 7.01 & 6.82 & 7.73 & 8.20 & 7.59 \\
\hline & 48 & 6.13 & 7.38 & 8.84 & 7.45 & 7.01 & 7.87 & 9.02 & 7.97 \\
\hline \multicolumn{2}{|r|}{ Mean } & 6.06 & 7.12 & 8.52 & 7.23 & 6.92 & 7.80 & 8.61 & 7.78 \\
\hline \multirow{3}{*}{$80 \% \mathrm{ET}_{\mathrm{c}}$} & 24 & 9.19 & 9.72 & 10.56 & 9.82 & 9.61 & 10.41 & 10.92 & 10.31 \\
\hline & \multirow[b]{2}{*}{ Mean } & 9.46 & 10.17 & 11.36 & 10.33 & 10.11 & 10.58 & 11.42 & 10.70 \\
\hline & & 9.32 & 9.95 & 10.96 & 10.08 & 9.86 & 10.50 & 11.17 & 10.51 \\
\hline \multirow{3}{*}{$100 \% \mathrm{ET}_{\mathrm{c}}$} & 24 & 10.15 & 10.41 & 11.29 & 10.62 & 11.11 & 11.60 & 12.55 & 11.75 \\
\hline & \multirow[b]{2}{*}{ Mean } & 10.06 & 11.08 & 11.47 & 10.87 & 11.50 & 12.26 & 13.50 & 12.42 \\
\hline & & 10.11 & 10.75 & 11.38 & 10.75 & 11.31 & 11.93 & 13.02 & 12.09 \\
\hline Potassiumx & 24 & 8.44 & 8.99 & 10.01 & 9.15 & 9.18 & 9.91 & 10.56 & 9.88 \\
\hline Nitrogen & 48 & 8.55 & 9.54 & 10.56 & 9.55 & 9.54 & 10.24 & 11.31 & 10.36 \\
\hline \multicolumn{2}{|r|}{ Mean } & 8.50 & 9.27 & 10.29 & & 9.36 & 10.08 & 10.93 & \\
\hline \multicolumn{10}{|c|}{ LSD at 0.05 level for: } \\
\hline \multicolumn{2}{|c|}{ Water regimes $(\mathrm{A})$} & \multicolumn{2}{|c|}{0.73} & $A \times C$ & 0.50 & A & 0.28 & $A \times C$ & 0.23 \\
\hline Potassium I & evels (B) & & & $B \times C$ & NS & B & 0.11 & $B \times C$ & 0.19 \\
\hline Nitrogen lev & els (C) & & & $\mathrm{AxB} \times \mathrm{C}$ & NS & C & 0.13 & $\mathrm{~A} \times \mathrm{B} \times \mathrm{C}$ & NS \\
\hline$A \times B$ & & & & & & $A \times B$ & NS & & \\
\hline & & & & & Root yie & ton/fed) & & & \\
\hline & 24 & 12.85 & 15.42 & 19.22 & 15.83 & 13.77 & 16.55 & 19.68 & 16.67 \\
\hline $60 \% \mathrm{ET}_{\mathrm{c}}$ & 48 & 15.70 & 18.03 & 20.85 & 18.19 & 15.01 & 18.05 & 21.10 & 18.05 \\
\hline & Mean & 14.27 & 16.72 & 20.04 & 17.01 & 14.39 & 17.30 & 20.39 & 17.36 \\
\hline $80 \%$ FT & 24 & 18.16 & 19.76 & 21.86 & 19.93 & 16.84 & 19.24 & 22.39 & 19.49 \\
\hline $80 \% \mathrm{El}_{\mathrm{c}}$ & 48 & 18.75 & 20.52 & 23.01 & 20.76 & 17.36 & 19.99 & 22.60 & 19.98 \\
\hline & Mean & 18.46 & 20.14 & 22.43 & 20.34 & 17.10 & 19.61 & 22.49 & 19.74 \\
\hline $100 \% \mathrm{FT}$ & 24 & 20.78 & 21.97 & 24.32 & 22.36 & 20.66 & 22.89 & 25.26 & 22.94 \\
\hline $100 \% \mathrm{EI}$ & 48 & 22.86 & 23.60 & 25.93 & 24.13 & 22.45 & 24.85 & 26.93 & 24.75 \\
\hline & Mean & 21.82 & 22.78 & 25.13 & 23.24 & 21.56 & 23.87 & 26.10 & 23.84 \\
\hline Potassiumx & 24 & 17.26 & 19.05 & 21.80 & 19.37 & 17.09 & 19.56 & 22.44 & 19.70 \\
\hline Nitrogen & 48 & 19.10 & 20.71 & 23.26 & 21.03 & 18.27 & 20.96 & 23.54 & 20.93 \\
\hline & Mean & 18.18 & 19.88 & 22.53 & & 17.68 & 20.26 & 22.99 & \\
\hline LSD at 0.05 & level for: & & & & & & & & \\
\hline Water regim & hes $(A)$ & & & $A \times C$ & 0.49 & A & 0.38 & $A \times C$ & 0.66 \\
\hline Potassium I & evels (B) & & & $B \times C$ & NS & B & 0.31 & $B \times C$ & NS \\
\hline Nitrogen lev & els $(C)$ & & & $\mathrm{A} \times \mathrm{B} \times \mathrm{C}$ & NS & $\mathrm{C}$ & 0.38 & $\mathrm{~A} \times \mathrm{B} \times \mathrm{C}$ & NS \\
\hline$A \times B$ & & & & & & $A \times B$ & 0.54 & & \\
\hline & & & & & ugar yie & (ton/fed & & & \\
\hline $60 \% \mathrm{FT}$ & 24 & 1.80 & 2.35 & 2.89 & 2.35 & 2.03 & 2.65 & 3.05 & 2.58 \\
\hline$b 0 \% \in I_{c}$ & 48 & 2.27 & 2.76 & 3.03 & 2.69 & 2.33 & 2.95 & 3.38 & 2.89 \\
\hline & Mean & 2.04 & 2.56 & 2.96 & 2.52 & 2.18 & 2.80 & 3.22 & 2.73 \\
\hline & 24 & 2.71 & 3.39 & 3.58 & 3.23 & 2.71 & 3.35 & 3.69 & 3.25 \\
\hline $80 \% \in I_{c}$ & 48 & 2.80 & 3.55 & 3.62 & 3.32 & 2.84 & 3.83 & 3.91 & 3.52 \\
\hline & Mean & 2.76 & 3.47 & 3.60 & 3.28 & 2.77 & 3.59 & 3.80 & 3.39 \\
\hline & 24 & 3.01 & 3.44 & 3.83 & 3.43 & 3.38 & 3.99 & 4.19 & 3.85 \\
\hline $100 \% \in I_{c}$ & 48 & 3.42 & 3.81 & 4.05 & 3.76 & 3.77 & 4.33 & 4.47 & 4.19 \\
\hline & Mean & 3.22 & 3.62 & 3.94 & 3.59 & 3.58 & 4.16 & 4.33 & 4.02 \\
\hline Potassiumx & 24 & 2.51 & 3.06 & 3.43 & 3.00 & 2.71 & 3.33 & 3.65 & 3.23 \\
\hline Nitrogen & 48 & 2.83 & 3.37 & 3.57 & 3.26 & 2.98 & 3.70 & 3.92 & 3.53 \\
\hline & Mean & 2.67 & 3.22 & 3.50 & & 2.84 & 3.52 & 3.78 & \\
\hline LSD at 0.05 & level for: & & & & & & & & \\
\hline Water regim & hes $(A)$ & & & $A \times C$ & 0.12 & A & 0.18 & $A \times C$ & 0.17 \\
\hline Potassium I & evels (B) & & & $B \times C$ & NS & B & 0.08 & $B \times C$ & NS \\
\hline Nitrogen lev & els (C) & & & $\mathrm{A} \times \mathrm{B} \times \mathrm{C}$ & NS & C & 0.10 & $\mathrm{~A} \times \mathrm{B} \times \mathrm{C}$ & NS \\
\hline$A \times B$ & & & & & & $A \times B$ & NS & & \\
\hline
\end{tabular}

NS: Insignificant difference. 
Results revealed that $\mathrm{K}$ fertilizer levels increased sugar yield statistically in the growing seasons. These results are in agreement with Mehrandish et al. (2012) and Neseim et al. (2014). An increment in sugar yield/fed amounted to $8.6 \%$ (0.26 ton) was recorded when beet plants were fertilized with $48 \mathrm{~kg} \mathrm{~K} \mathrm{~K} / \mathrm{fed}$, in the $1^{\text {st }}$ season and $9.28 \%$ ( 0.30 ton) in the $2^{\text {nd }}$ one compared to those supplied with $24 \mathrm{~kg}$ $\mathrm{K}_{2} \mathrm{O} / \mathrm{fed}$. These results may be due to potassium's role in increasing sucrose, extractable sugar and purity percentages (Table 6) and root yield (Table 7).

Results in Table 7 pointed out that the increasing nitrogen levels to 100 and $120 \mathrm{~kg}$ $\mathrm{N} /$ fed increased sugar yield/fed by $20.59 \%$ (0.55 ton) and $31.08 \%\left(0.83\right.$ ton) in the $1^{\text {st }}$ season, corresponding to $23.94 \%$ ( 0.68 ton) and $33.09 \%\left(0.94\right.$ ton) in the $2^{\text {nd }}$ season, respectively compared to $80 \mathrm{~kg} \mathrm{~N} / \mathrm{fed}$. The same trend were found by Amin et al. (2013) and El-Geddawy and Makhlouf (2015). The effectiveness of raising $N$ fertilizer levels on sugar yield could be referred to its positive influence on root yields/fed (Table 7).

Sugar yield/fed was significantly affected by the interaction between the examined IWR and $\mathrm{K}$ levels in the $1^{\text {st }}$ season.
The interaction between water regimes and nitrogen levels showed a significant influence on sugar yield/fed, in both seasons. In the $1^{\text {st }}$ season, it was noticed that raising $N$ fertilization level from 80 to $100 \mathrm{~kg} \mathrm{~N} / \mathrm{fed}$ increased sugar yield/fed by $0.52,0.71$ and 0.40 tons, corresponding to increases of $0.92,0.84$ and 0.72 tons as $\mathrm{N}$ level was increased from 80 to $120 \mathrm{~kg} \mathrm{~N} / \mathrm{fed}$, when sugar beet was irrigated at 60,80 and $100 \% \mathrm{ET}_{\mathrm{c}}$, successively. Similar trend was observed in the $2^{\text {nd }}$ season. Moreover, these results showed that irrigation deficit at $60 \%$ and $80 \% \mathrm{ET}_{\mathrm{c}}$ achieved the highest water use efficiency, compared to that gained by applying water at $100 \% \mathrm{ET}_{\mathrm{c}}$.

\section{Water Use Efficiency (WUE):}

Mathematical models that best fit the relation between amounts of applied irrigation water $\left(\mathrm{m}^{3} / \mathrm{fed}\right)$ and WUE for sugar beet root and sugar yields were developed for the two growing seasons. The obtained models for WUE of root yields (Fig. 1) in the two seasons were:

$$
\begin{aligned}
\text { WUE root yield }= & -3.6561 \mathrm{Ln}(\mathrm{AIW})+37.419 \\
& \mathrm{R}^{2}=0.99 \\
\text { WUE root yield }= & -3.7246 \mathrm{Ln}(\mathrm{AIW})+37.998 \\
& \mathrm{R}^{2}=0.91
\end{aligned}
$$

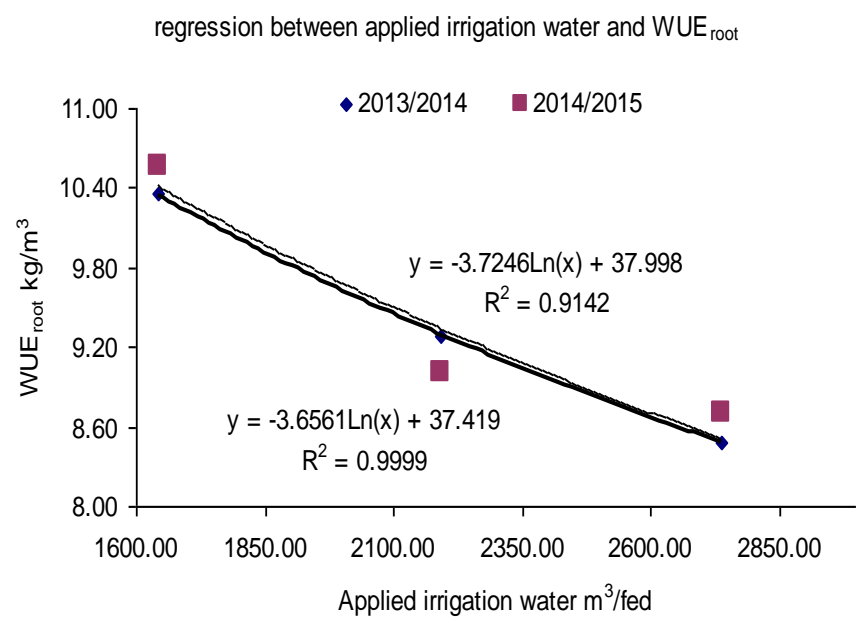

Fig. 1: Logarithmic regression between applied irrigation water and water use efficiency for root yield. 


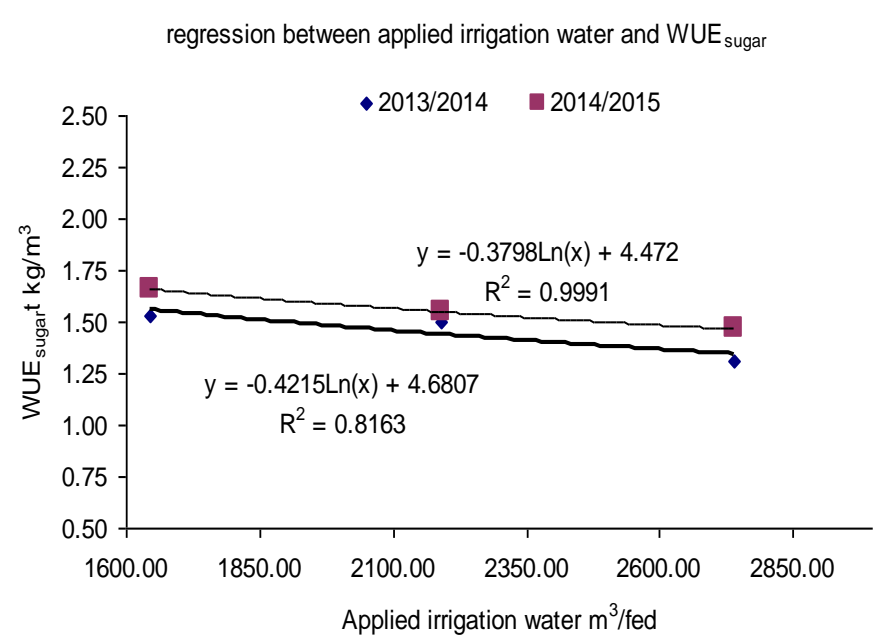

Fig. 2: Logarithmic regression between applied irrigation water and water use effeciency for sugar yield.

The obtained models for WUE based on sugar yields (Fig. 2) in the two seasons were:

WUE $_{\text {sugar yield }}=-0.4215 \mathrm{Ln}(\mathrm{AIW})+4.681$ $\mathrm{R}^{2}=0.82$

WUE sugar yield $=-0.3798 \mathrm{Ln}(\mathrm{AIW})+4.472$ $\mathrm{R}^{2}=0.99$

The highest values of the coefficient of determination $\left(R^{2}>0.9\right)$ indicate that the given equations can be used within the range of the examined values to describe the relation between amounts of applied irrigation water and water use efficiency for root and sugar yields.

Results illustrated in Figure 3 show the values of WUE for sugar beet root yields as affected by irrigation regime treatments in the two growing seasons. Results indicated, in general, that WUE values for root yield incresed with decreasing the amounts of applied irrigation water. The obtained WUE $_{\text {root }}$ values increased from $8.49 \mathrm{~kg} / \mathrm{m}^{3}$ for the $100 \% \mathrm{ET}_{\mathrm{c}}$ treatment to 9.29 and
$10.35 \mathrm{~kg} / \mathrm{m}^{3}$ for the $80 \% \mathrm{ET}_{\mathrm{c}}$ and $60 \% \mathrm{ETC}$ regimes, respectively in the $1^{\text {st }}$ growing season. The same trend was found in the $2^{\text {nd }}$ one, where the relative increase in $W E_{\text {root }}$ values due to difecit irrigation regimes were $3.5 \%$ and $21.9 \%$ for the $80 \%$ $\mathrm{ET}_{\mathrm{c}}$ and $60 \% \mathrm{ET}_{\mathrm{c}}$ treatments, respectively. For the WUE values of sugar yield, results illustrated in Fig. 4 show that, there is a positive response in $W_{U} E_{\text {sugar }}$ values with decreasing the amounts of applied irrigation water. The $W U E_{\text {sugar }}$ values increased from $1.31 \mathrm{~kg} \mathrm{sugar} / \mathrm{m}^{3}$ for the $100 \% \mathrm{ET}_{\mathrm{c}}$ to 1.50 and $1.53 \mathrm{~kg}$ sugar $/ \mathrm{m}^{3}$ for the $80 \%$ and $60 \%$ $\mathrm{ET}_{\mathrm{c}}$ treatments, respectively in the $1^{\text {st }}$ growing season and from $1.47 \mathrm{~kg}$ sugar $/ \mathrm{m}^{3}$ for the $100 \% E T_{c}$ to 1.55 and $1.66 \mathrm{~kg}$ sugar $/ \mathrm{m}^{3}$ for the same respective treatments in the $2^{\text {nd }}$ growing season. The obtained results indicated that difecit irrigation is a good tool to increase water use effeciency for suger beet crop grown under sandy soil conditions. 


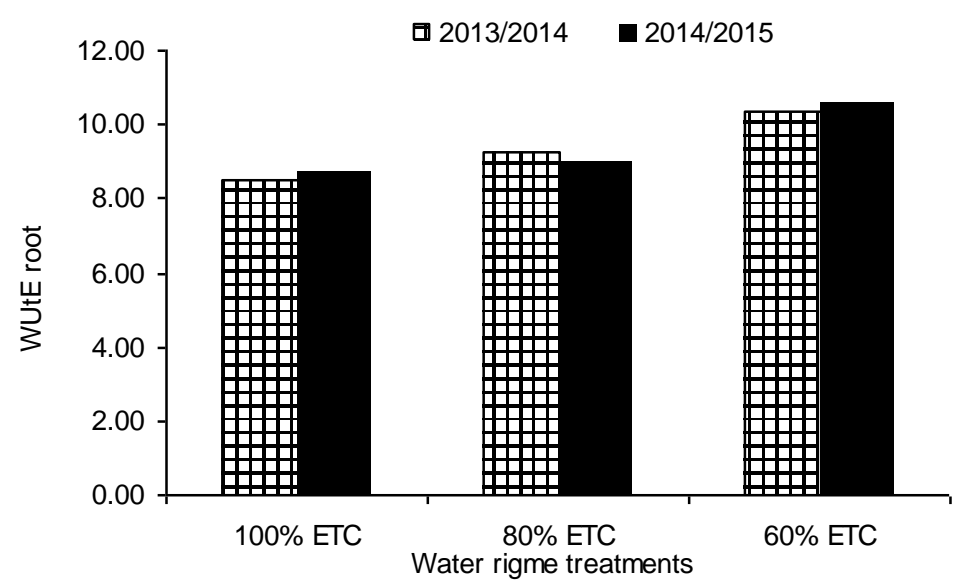

Fig. 3: Water use efficiency for sugar beet root yield as affected by irrigation regimes.

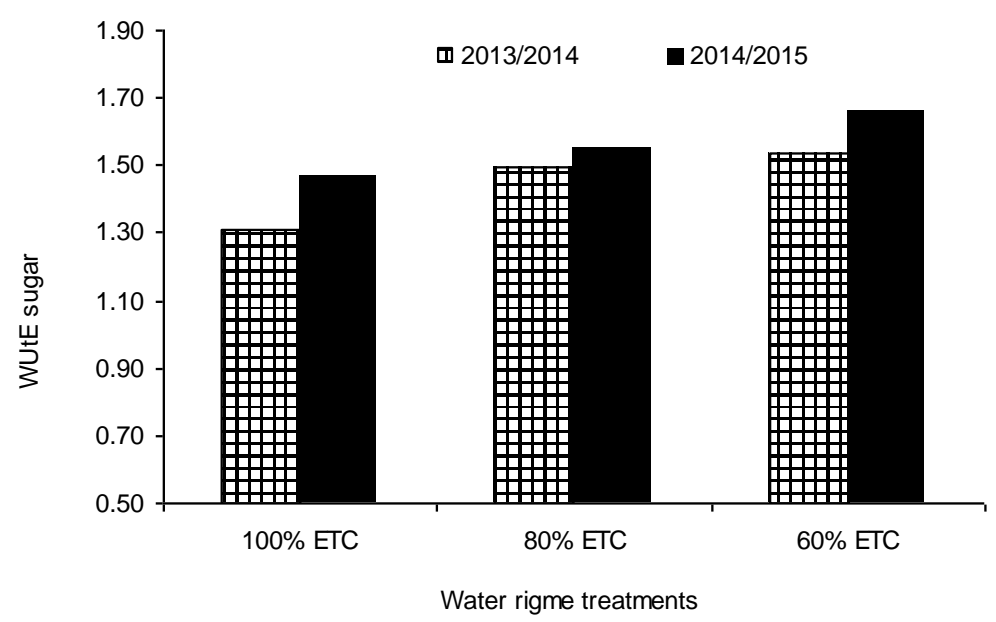

Fig. 4: Water use efficiency for sugar yield as affected by irrigation regimes.

\section{CONCLUSION}

Under conditions of El-Bostan area, ElBuhira Governorate, the combination of "Supplying sugar beet with irrigation water at $80 \%$ ET $\left(2191 \mathrm{~m}^{3}\right.$ water/fed $)+100 \mathrm{~kg} \mathrm{~N}+$ $48 \mathrm{~kg} \mathrm{~K} 2 \mathrm{O} / \mathrm{fed}$ " can be recommended to get the best quality traits. However, applying irrigation water at $100 \% \mathrm{ET}_{\mathrm{c}}\left(2739 \mathrm{~m}^{3}\right.$ water/fed) + $120 \mathrm{~kg} \mathrm{~N}+48 \mathrm{~kg} \mathrm{~K}{ }_{2} \mathrm{O} / \mathrm{fed"}$ can be recommended to get the highest yields of top, root and sugar/fed. The highest WUE for root and sugar yield was obtained with $60 \% \mathrm{ET}_{\mathrm{c}}$.

\section{REFERENCES}

Amin, A.G., E.A. Badr and M.H.M. Afifi

(2013). Root yield and quality of sugar beet (Beta vulgaris L.) in response to biofertilizer and foliar application with micro-nutrients. World Appl. Sci. J., 27(11): 1385-1389.

Allen, R.B., L.S. Pereira, D. Raes and M. Smith (1998). Crop evapotranspiration. Irrig. Drain. Paper 56, Food and Agric. Org. UN, Rome, Italy. p 300.

Badr, A.I. (2016). Importance of nitrogen and microelements for sugar beet 
production in sandy soils. J. Plant Prod., Mansoura Univ., 7(2): 283-288.

Barlog, P., W. Grzebisz, K. Peplinski and W. Szczepaniak (2013). Sugar beet response to balanced nitrogen fertilization with phosphorus and potassium part $i$. dynamics of beet yield development. Bulgarian J. Agric. Sci., 19(6), 1311-1318.

Bloch, D., C.M. Hoffmann and B. Marlander (2006). Impact of water supply on photosynthesis, water use and carbon isotope discrimination of different sugar beet genotypes. Eur. J. Agron., 24:218225.

Brown, J.D. and O. Lilliand (1964). Rapid determination of potassium, sodium in plant material and soil extraction by flame photometry. Proc. Amer. Soc. Hort. Sci., 48:340-364.

Chapman, H.D. and R.E. Pratt (1961). Methods of Analysis for Soil, Plants and Water. Dept. Soil, Plant Nut., Univ. California, USA.

Chutia, J. and S.P. Borah (2012). Water stress effects on leaf growth and chlorophyll content but not the grain yield in traditional rice (Oryza sativa Linn.) genotypes of assam, India II. Protein and Proline Status in Seedlings under PEG Induced Water Stress. Amer. J. Plant Sci., 3:971-980.

Clover, G.R.G., H.G. Smith, S.N. Azam-Ali and K.W. Jaggard (1999). The effects of drought on sugar beet growth in isolation and in combination with beet yellows virus. J. Agric. Sci., 133:251-261.

Dexter, S.T., M.G. Frankes and F.W. Snyder (1967). A rapid and practical method of determining extractable white sugar as may be applied to the evaluation of agronomic practices and grower deliveries in the sugar beet industry. J. Amer., Soc., Sugar Beet Technol., 14:433-454.

Deviller, P. (1988). Prevision du sucre melasse sucrerie feanases.129:190-200. [C.F. Cooke, D.A. and R.K. Scott (1993) The Sugar Beet Crop Book].
Dreesman, D.C., C. Harn and J. Daie (1994). Expression of genes encoding rubisco in sugarbeet (Beta vulgaris L.) plants subjected to gradual desiccation. Plant cell physiol., 35(4):645-653.

Dunham, R.J. (1995). The sugar beet crop: water use and irrigation. Edited by: Cooke, D.A. and Scott, R.K. Chapman \& Hall, London, $285 \mathrm{pp}$.

El-Geddawy, Dalia I.H. and B.S.I. Makhlouf (2015). Effect of hill spacing and nitrogen and boron fertilization levels on yield and quality attributes in sugar beet. Minufiya J. Agric. Res., 4(1): 959980.

El-Sarag, Eman, I. and S. H. Moselhy (2013). Response of sugar Beet quantity and quality to Nitrogen and potassium Fertilization under sandy soils conditions. Asian J. crop Sci., 5(3): 295-303.

English, M. and S.J. Raja (1996). Perspectives on deficit irrigation. Agric. Water Manag., 32: 1-14.

Esmaeili, M.A. (2011). Evaluation of the effect of water stress and different level of nitrogen on sugar beet (Beta vulgaris L.). Intr. J. Biol., 3(2): 89-93.

Grzebisz, W., A. Gransee, W. Szczepaniak and J. Diatta (2013). The effects of potassium fertilization on water-use efficiency in crop plants. J. Plant Nut. Soil Sci., 176(3):355-374.

Hosseinpour, M., A. Sorooshzadeh, M. Aghaalikhani, D.F. Taleghani and $M$. Khoramian (2006). The effect of irrigation in spring on water use efficiency and yield of autumn sown sugar beet. J. Sugar Beet, 22(2): 35-52.

Hussein, M.M., H. Mehanna, H.S. Siam; Safaa A. Mahmoud and A.S. Taalab (2015). Mineral Status, Growth and Yield Response of Sugar Beet (Beta Vulagaris L.) to Nitrogen Fertilizer Sources and Water Regime Adv. Environ. Biol., 9(27): 1-11.

Ismail, S.M. (2002). Design and Management of field Irrigation System. (in Arabic), $1^{\text {st }}$ Ed, Monshaet El-Maaref Pupl., Alex., Egypt. 
Jackson, M.L. (1967). Soil chemical analysis, prentice- hall India private limited, New York.

Jensen, M.E. (1983). Design and operation of farm irrigation systems. ASAE, Michigan, USA., p. 82.

Kandil, A.A., M.A. Badawi, S.A. El-Moursy and U.M.A. Abdou (2002). Effect of planting dates, nitrogen levels and biofertilization treatments on: II- Yield, yield components and quality of sugar beet (Beta vulgaris, L.). J. Agric. Sci. Mansoura Univ., 27(11): 7257-7266.

Kant, S. and U. Kafkafi (2002). Potassium and Abiotic Stresses in Plants. In $\mathrm{N}$. Pasricha \& S. Bansal, eds. Potassium for sustainable crop production. Potash Inst. India, Gurgaon, pp. 233-251.

Le Docte, A. (1927). Commerical determination of sugar beet root using the sachr- Le-Docte process. Sugar J., 29:488-492.

$\mathrm{Li}$, Y.Y. and H. Liang (1997). Effects of Potassium Fertilizers on Sugar Beet Yield and Quality. Better Crops Inter. 11, No. 2, November.

Markus, D.K., J.P. Mckinnon and A.F. Buccafuri (1982). Automated Analysis of Nitrite and ammonium Nitrogen in soils. New Jersey Agric. Exp. Stn. Publ. No. D15117-84, USA.

Mehrandish, M., M.J. Moeini and M. Armin (2012). Sugar beet (Beta vulgaris L.) response to potassium application under full and deficit irrigation. European $\mathrm{J}$. Exper. Bio., 2(6):2113-2119.

Mahmoodi, R., H. Maralian and A. Aghabarati (2008). Effects of limited irrigation on root yield and quality of Sugar beet (Beta vulgaris L.).African. J. Biol. 7(24): 4475-4478.

Masri, M.I., B.S.B. Ramadan, A.M.A. ElShafai and M.S. El-Kady (2015). Effect of water stress and fertilization on yield and quality of sugar beet under drip and sprinkler irrigation systems in sandy soil. Int. J. Agric. Sci., (ISSN 2167-0447), 5(3): 414-425.
Mehran, S. and S. Samad (2013). Study of potassium and nitrogen fertilizer levels on the yield of sugar beet in jolge cultivar. J. Novel Appl. Sci., 2-4/94-100.

Neseim, M.R, A.Y. Amin and M.M.S. ElMohammady (2014). Effect of potassium applied with foliar spray of yeast on sugar beet growth and yield under drought stress. Global Adv. Res. J. Agric. Sci., 3(8):211-222 .

Pergl, F. (1945). Quantitative Organic Micro Analysis $4^{\text {th }}$ Ed. J. and Churchill Ltd., London.

Piper, C.S. (1950). Soil and Plant Anlysis. Inter. Sci. Publ. Inc., New York.

Selim, E.M., Z.M. Elsirafy and A.A. Taha (2010). Effect of irrigation methods and Napplications on the utilization of nitrogen by sugar beet grown under arid condition. Aust. J. Basic Appl., Sci., 4(7): 21142124.

Snedecor, G.W. and W.G. Cochran (1981). Statistical methods $7^{\text {th }}$ Ed., lowa State Univ. Press, Ames, lowa, USA.

Soltanpour, P. N. (1991). Determination of nutrient availability element toxicity by AB-DTPA. Soil Test and ICPS Adv. Soil Sci., 16:165-190.

Stewart, J.I. and R.M. Hagan (1973). Function to predict effect of crop water deficit. J. Irrig. Drain. Div., ASCE, 99, IR4: 421-439.

Tognetti, R., S. Delfine, P. Sorella and A. Alvino (2002). Responses of sugar beet to drip and low-pressure sprinkler irrigation systems: root yield and sucrose accumulation. Agric. Medit., 132(1): 1-8.

Ucan. K. and C. Gencoúglan (2004). The effect of water deficit on yield and yield components of sugar beet. Turk J. Agric., (28): 163-172.

Vermeirer, L. and G.A. Topling (1984). localized irrigation FAO. Irrigation paper No.36. Rome, Italy.

Waller, R.A. and D.B. Duncan (1969). A bays rule for symmetric multiple comparison problem. Amer. Stat. Assoc. J., 1485-1503. 
Wang, M., Q. Zheng, Q. Shen and S. Guo (2013). The critical role of potassium in plant stress response. Int. J. Molec. Sci., 14(4):7370-7390.

Watson, D.J. (1952). The physiological basis of variation in yield. Adv. Agron. 4:101145.

Watson, D.J. (1958). The dependence on leaf area index. Annal. Bot., London, 85(22): 37-54.

Weeden, B.R. (2000). Potential of sugar beet on the Atherton Tableland. A report for the rural industries research and development corporation (RIRDC), Publ. No. 00/167, Project No. DAQ 211A, Barton. Pp. 2-14.

Wettestien, D.V. (1957). Chlorophyll -Letal und from weehsel der plastiden- EXP. Cell Res. 12: 427.

Xiang, D.B., L.X. Peng, J.L. Zhao, L. Zou, G. Zhao and C. Song (2013). Effect of drought stress on yield, chlorophyll contents and photosynthesis in tartary buckwheat (Fagopyrum tataricum). Food, Agri. Environ. (JFAE), 11(3-4):1358-1363.

\section{تأثير نقص الري والتسميد النيتروجينى والبوتاسى على إنتاجية بنجر السئكَر في الأراضي الرملية}

باسـ صبحي إبراهيم مخلوف(1) ، أحمد إسماعيل أحمد عبد العال(2)

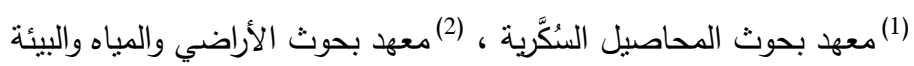

مركز البحوث الزراعية ، الجيزة ، مصر

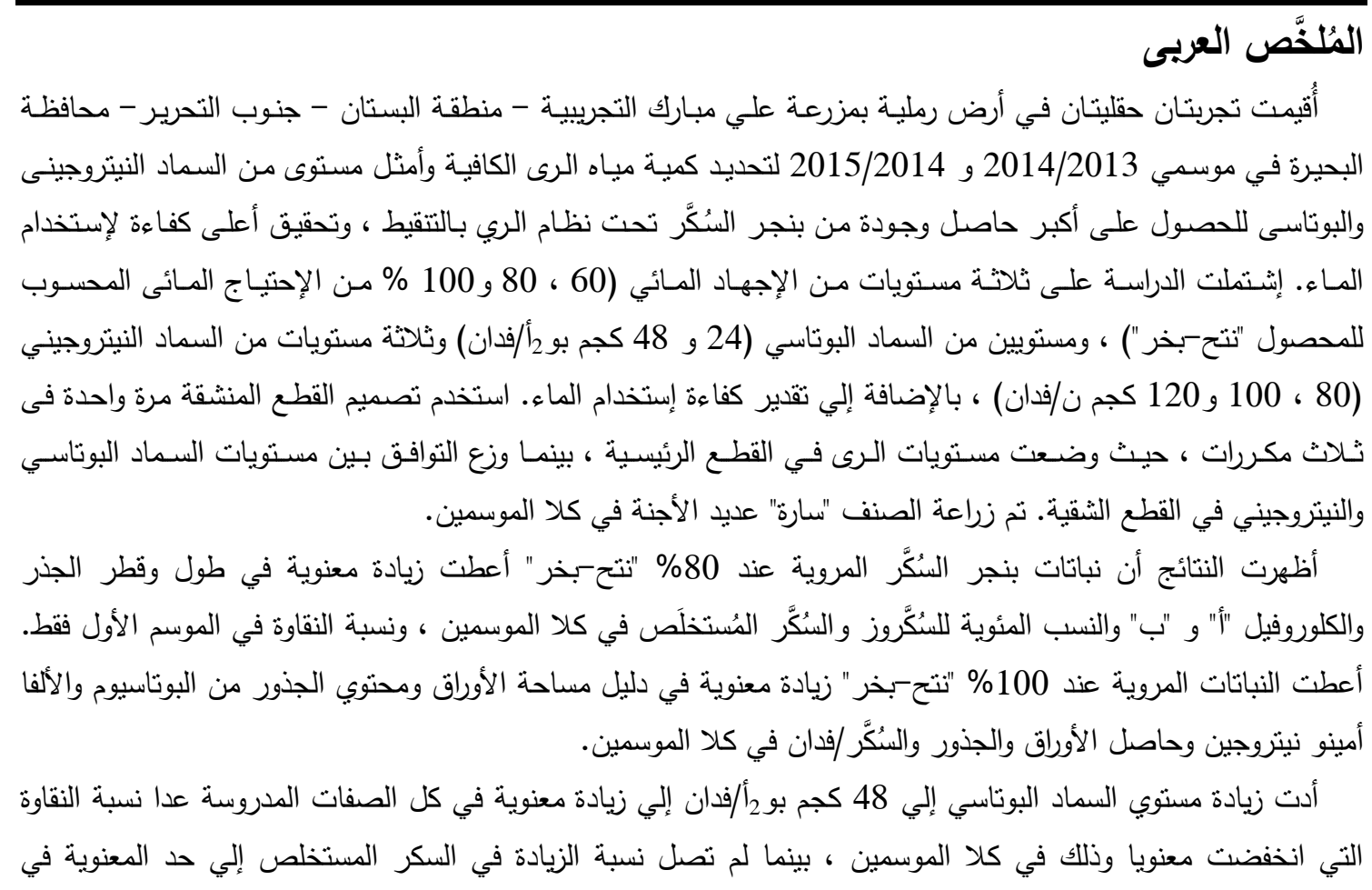


الموسم الأول. نم الحصول على زيادة معنوية فى طول وقطر الجذر ومحتوي الجذور من الصوديوم والبوتاسيوم والألفا أمينو

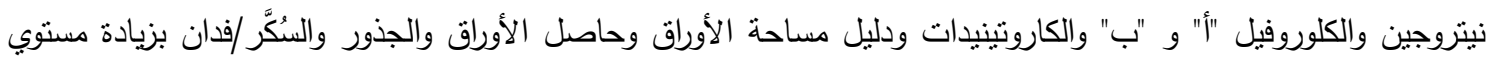

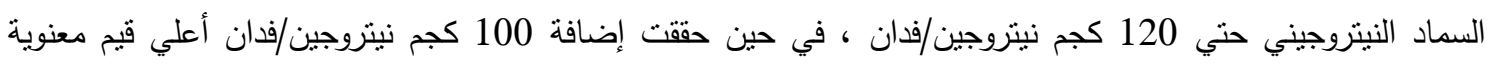

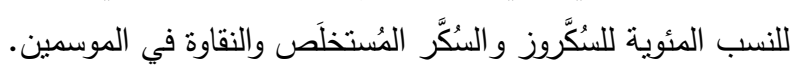

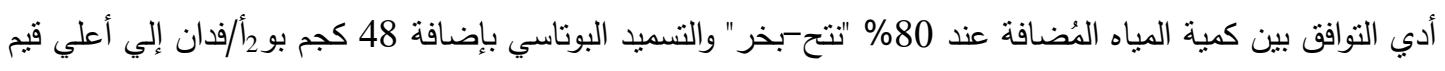

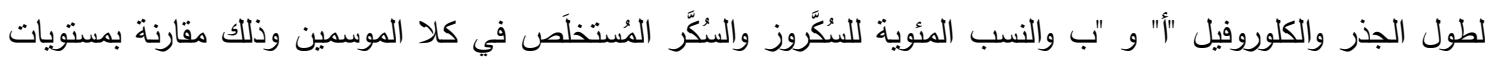

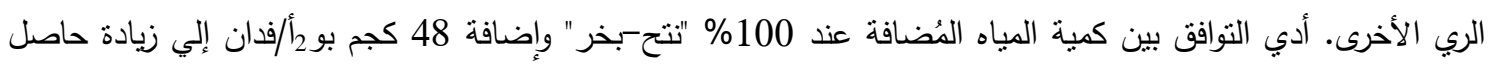

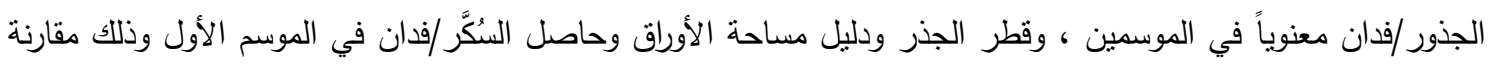

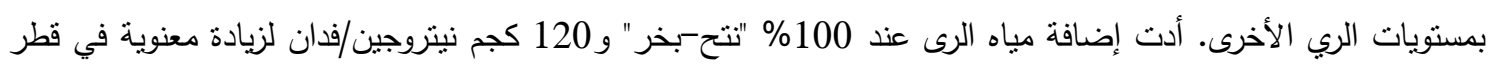

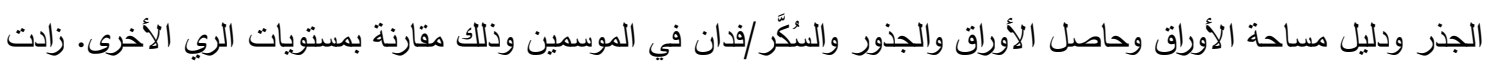

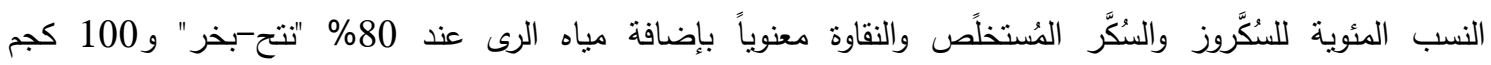

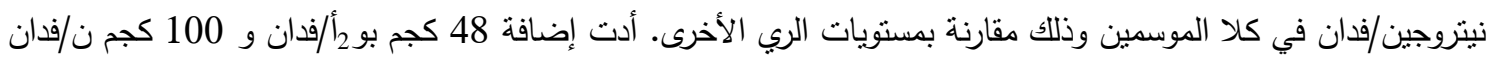

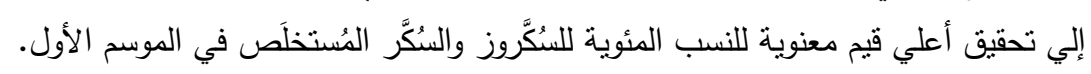

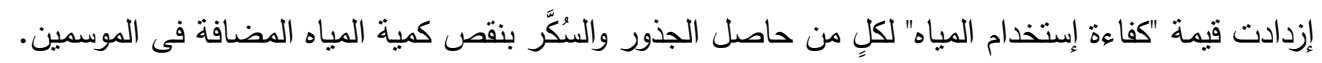

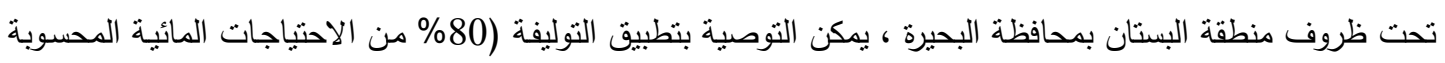

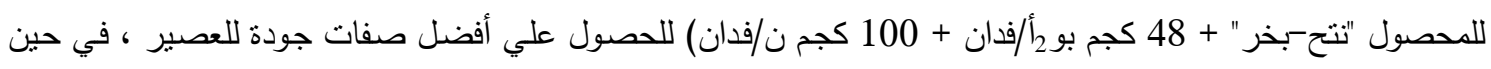

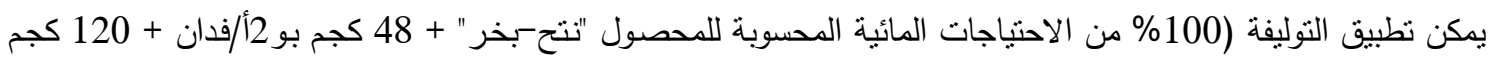
ن/فدان) للحصول علي أعلي حاصل للأوراق والجذور والسُكَّر للفدان. 
Effect of deficit irrigation, nitrogen and potassium fertilization on sugar...... 